\title{
Marka İmajı Üzerine Türkçe Duygu Sözlügü̈ Geliştirme Çalışması
}

\section{A Study To Develop A Turkish Sentiment Lexicon On Brand Image}

\author{
Emel Özdemir Akcan ${ }^{1}$ (1)
}

${ }^{1}$ (Doktora Öğrencisi), Sakarya Üniversitesi, İşletme Enstitüsü, Sakarya, Türkiye

ORCID: 0000-0003-2068-5265

\section{Corresponding author:}

Emel Özdemir AKCAN

Sakarya Üniversitesi, İşletme Enstitüsü, Sakarya,

Türkiye

E-mail address:

emel.ozdemir2@ogr.sakarya.edu.tr

Submitted: 02.04 .2021

Revision Requested: 13.07 .2021

Last Revision Received: 30.07 .2021

Accepted: 04.08.2021

Published Online: 14.10 .2021

Citation: Ozdemir Akcan, E. (2021). A study to develop a turkish sentiment lexicon on brand image. Acta Infologica, 5(2), 415-433. https://doi.org/10.26650/acin. 908724

\begin{abstract}
ÖZ
Son yıllarda kullanıcıların yorum ve düşüncelerini belirleyebilmek, markalar hakkındaki düşünce ve duygularını ortaya çıkarabilmek amacı ile duygu analizi, işletmeler açısından en kullanışlı yöntemlerden birisi olarak karşımıza çıkmaktadır. Yöntem bilimsel bakış açısıyla genel sözlüklerin marka imajı alanına ait marka terimlerini yeteri kadar temsil edememesi, Türkçe olarak marka bağlamında duygu sözlüğ̈nün yer almaması ve marka imajını duygu analizi ile ortaya koyan çalışmaların son derece az olması, bu alandaki eksikliği ortaya koymaktadır. Bu kapsamda bu araştırmanın amacı markaların kullanıcıların zihnindeki imaj algısını belirleyebilmek adına duygu analizi için gerekli olan bir Türkçe sözlük oluşturmaktır.

Bu amacı gerçekleştirmek için, marka imajı ile ilgili yükseköğretim kurumundaki (YÖK) 113 Türkçe tez taranarak, içerisinde en çok geçen kelimeler R programlama dili kullanılarak, duygu analizi yöntemi ile tespit edilmeye çalışılmıştır. Marka imajı alanına ait veri setinde toplamda elde edilen kelime sayısı 1.738.596 adet olarak gözlemlenmiştir. Bu kelimeler içerisinde marka imajı alanında en sık kullanılanlar ise 31.671 adet kelime olarak elde edilmiştir. En sık kullanılan 31.671 kelimenin içerisinde marka imajı alanında duygu ifade eden 9535 adet kelime ile marka imajı sözlüğünü oluşturulmuştur.
\end{abstract}

Anahtar kelimeler: Marka imajı, Sosyal Medya, Duygu Analizi, R, Duygu Sözlüğü

\section{ABSTRACT}

In recent years, sentiment analysis has emerged as one of the most useful methods for businesses in order to determine the comments and thoughts of users, to reveal their opinion and emotions about brands. From a methodological perspective, the fact that general lexicons do not adequately represent brand terms in the domain of brand image, that there is no sentiment lexicon in Turkish in the context of the brand, and the fact that there are very few studies that reveal the brand image with sentiment analysis reveal the deficiency in this domain. In this context, the purpose of this research is to create a Turkish lexicon that is necessary for sentiment analysis in order to determine the perception of the image of the brand in users' minds. In order to achieve this aim, 113 Turkish theses in the higher education institution (YÖK) related to brand image were scanned, and the most frequently mentioned words in them were tried to be determined with the sentiment analysis method by $\mathrm{R}$ programming language.

The total number of words obtained in the data set of the field of brand image was observed as $1,738,596$. Among these words, the most frequently used words in the field of brand image were obtained as 31,671. The brand image lexicon was created with 9535 words which express sentiment in the domain of brand image among the 31,671 words used most frequently.

Keywords: Brand Image, Social Media, Sentiment Analysis, R, Sentiment Lexicon 


\section{GİRIŞ}

İnternet çok sayıda elektronik aygıtın birbiri ile bağlantılı olduğu, evrensel olarak kullanılan ve gün geçtikçe kullanıcı sayısı artan bir haberleşme aracıdır. Sosyal medya mecraları ise internette kullanıcıların birbiri ile iletişime geçtikleri en önemli bilgi paylaşım ağlarından birisidir (https://www.statista).

Sosyal medya mecraları, markaların tüketicilerin zihninde oluşturdukları yeri görebilmeleri ve tüketici zihninde marka konumunu güçlendirebilmeleri için, işletmelerin ihtiyaçlarına cevap verebilecek ortamlar olarak karşımıza çıkmaktadır. Çünkü bu ortamlarda müşteriler, bir markaya yönelik ürün ve hizmetler hakkında özgür yorumlar yapabilmekte, görüş ve fikirlerini paylaşmakta, tavsiye ve şikâyette bulunabilmektedirler. Tüketiciler bu anlamda pasif konumdan çıkarak aktif bir konuma gelmekte ve işletmelerin marka imajlarını olumlu veya olumsuz olarak belirleyebilmektedirler. Sosyal ağlarda etkileşim içerisinde olan yeni bir hedef kitlenin bulunması işletmelere, rekabet analizi, imaj yönetimi, stratejik konumlandırma, halkla ilişkiler ve marka yönetimi gibi alanlarda olumlu ve olumsuz niteliklerini görebilme ve yönetebilme imkânı sunmaktadır.

Çağdaş markalaşma yaklaşımı genel olarak tüketici tutumları, sadakat, imaj algısı ve markaya yapılan konumlandırma faaliyetleri üzerine odaklanmıştır. Markalaşma ve önemine yönelik ilk tartışmalara Smith, (1915) ve Copeland (1923) gibi pazarlama araştırmacılarının çalışmalarında rastlamaktayız. Bu yazarlara göre, bireyler, üretici tarafından oluşturulmak suretiyle tanınmayı sağlayan ve olumlu çağrışımları olan bir marka ismi var olmadığı sürece bir ürünü satın alma sürecinde gönülsüz olabileceklerini ileri sürmüşlerdir. Genel olarak bakıldığında, bir kurumun ancak marka portföyünü incelikli bir biçimde yönetip bu doğrultuda doğru konumlandırma yapabildiği durumlarda başarılı olabildiği görülmektedir (Christodoulides ve Chernatony,2010; Srinivasan vd.,2005; Park ve Srinivasan,1994; Davcik ve Rundquist, 2012; Paswan vd., 2012). Daha sonraki dönemlerde, Gardner ve Levy gibi araştırmacılar tüketicilerin ürünleri birbirinden ayırt etmelerine yarayan basit etiketlerin çok daha ötesinde anlamlar içerdiklerini ifade etmişlerdir. Bu anlamlar markalar üzerinden farklılaştırma, fayda beklentileri kalite ve performans ile ilgili ya da öznel tüketici değerlendirmelerini içermektedir. Ayrıca Gardner ve Levy’ye göre tüketicilerin markalara karşı oluşturdukları bu anlamlar duygu, fikir ve tutumların bütünü olarak satın alma tercihlerinde önemli bir faktör olarak görülmektedir. Kurumsal reklam yöneticileri ve sektörel araştırmalar marka imajını kurumların en önemli gücü olarak ifade etmektedirler (Gardner ve Levy, 1955).

Tüketicilerin, çoğu kez bir markayla ilgili akıllarında kalan çağrışımları ile birlikte, zihinlerinde bir marka imajı oluşmaktadır. Oluşan bu maka imajı kavramı, bireysel olarak algıdaki seçicilik ile beraber kişiye özeldir. Buna karşın bazı marka imajı tanımlamaları markaya dair geçmiş deneyim ve yaşanmışlıkların etkili olduğu yönündedir (Chia-Hung, 2008). Marka imajı için, tüketicinin markaya dair bağdaştırdığı çağrışımlar ve tanımlamalar kümesi denilebilir. Bu çağrışımlar, markanın kendine has özellikleri veya derinlemesine yarattığı algılardır (Aaker and Biel, 1993: 71). Bir başka yaklaşım ise marka imajının bir yöne kanalize edilmiş çağrışım kümesi olduğu veya bir markanın tüketicilerine sunduğu marka kültürünün sonucu olarak, markaya ilişkin sahip olunan yargılar, tutumlar ve değerler toplamı olduğu yönündedir (Meenaghan, 1995). Marka imajına dair farklı bir yaklaşım da işletmenin sergilediği davranış ile ilgilidir. İşletmelerin sergiledikleri tutum ve davranışlar markalarınının pazardaki konumunu belirler. Böylece işletme faaliyetleri neticesinde marka konumlandırma, bir markanın, potansiyel kullanıcılarının zihnindeki algılamalardan oluşmaktadır. Marka konumlandırmayla, markanın pazardaki yeri, ulaştığı kitle ve tüketicilerin markaya bakış açısı belirlenmiş olur. Marka konumlandırma, geleceğe yönelik başarı hedefi olan tüm işletmelerin ana odağı olmalıdır. Çünkü tüketiciler her marka ile ilgili düşünceler oluşturmaktadır ve bu düşünceler işletmeler tarafından oluşturulmuştur. Bu nedenle de tüketicilerin zihinlerinde nasıl bir şekilde yer edeceğinizi yönetmek için, marka konumlandırma ve tüketici zihnindeki imaj değerlendirmelerine öncelik verilmesi gerekmektedir. İşletmelerin, piyasalardaki ve sosyal platformlardaki yeri tüketicilerin markanıza bakış açısını etkilediği için önemlidir. Tüketicilerin akıllarında ki imajınızın negatif çağrışımlar dan oluşması, kötü bir konumlanmanız olduğuna işarettir ve bu da müşteri kaçırmanıza neden olabilir. Aynı zamanda işletmelerin konumu, imajınızı etkileyerek, sadık müşteri kitleleri edinmenize de etki eder (ideasoft, 2021).

Dolayısı ile işletmelerin imajları herhangi bir nedenden ötürü zedelenirse, marka imajları da zedelenir. İmajı ve markası zedelenen bir işletme, pazar için yeni bir imaj yaratmak zorundadır. Kısacası marka imajı bir işletmenin veya markanın nasıl 
bilindiği ve nasıl algılandığına dair yargılardır. Bu bağlamda işletmelerin hedefleri; tüketicilerin zihinlerinde iyi bir izlenim ile birlikte kendisine has özellikleri olan imaj konumlandırması bırakmaktır (Clow and Baack, 2016: 24-25). Böylelikle işletmelerin tüketiciler zihnindeki konumlarını her an değerlendirmek ve takip etme ihtiyacı artmaktadır.

Buradan hareketle, kritik kararlar vermek açısından müşteri beklentilerini anlık olarak belirleyebilmek ve marka imajının yönetilmesi bakımından sosyal medya mecralarında tüketicilerin marka hakkındaki görüş, duygu ve düşüncelerini değerlendirmek ve takip etmek için duygu analizinden yararlanmak günümüzde zorunluluk haline gelmiştir (Chen vd., 2014; Akgül vd., 2016). Kurumların ürettikleri ürün, hizmet ve markalara ilişkin güçlü yanlarını, zayıf yanlarını takip edebilmeleri ve tüketiciler tarafından nasıl algılandığının analizini yapabilmeleri açısından sosyal medyada yer alan metin yığınları duygu ve fikirleri ortaya çıkarması sebebiyle çok önemli veriler barındırmaktadır. Büyük miktarlarda veri barındıran metinlerden anlamsal bilgi çıkarımı çok güç ve yüksek maliyetlidir (Fernández-Gavilanes vd., 2016). Bu anlanmada duygu analizi araçları büyük boyuttaki verileri analiz edebilmek için uygun araçlar olarak karşımıza çıkmaktadır (Türkmenoğlu, 2015).

Duygu analizi, insanların birçok konu ile ilgili, geliştirmiş oldukları tutum, tavır ve görüşlerini ifade ettikleri metinler içerisinde gizli kalmış olan duygu, fikir ve görüş bildiren bileşenlerin ortaya çıkarılmasını amaçlayan doğal dil işleme yönteminin bir alt dalı olarak karşımıza çıkmaktadır (Liu, 2020). Bir metin parçası ile belirtilen tutumlar çeşitli yöntemler aracılı̆̆ı ile sınıflandırma süreçlerine tabi tutulmaktadır.

Duygu analizi çalışmalarını etkin işleyebilmesi için önünde yer alan bazı engeller de göz önünde bulundurulmalıdır. Bu engellerden bazıları şu şekilde sıralanabilir; "İğneleyici İfadeler ve İroniler”, "Duygu Sözcüğü Yokluğu”, "Karmaşı Yapı”, "Gürültülü Veri”, "Olumsuzluk Ekleri” ve bu engellerin en başında gelen "Alan Bağımlılık” kısıtı analizlerin etkin bir şekilde yapılamamasına neden olmaktadır. Alan Bağımlılık, bazı kelimelerin farklı alanlarda kullanıldığında farklı duygu yönelimine sahip olabilmesi anlamına gelmektedir. Örneğin "Bugün hava çok sıcak, adeta nefes alamıyorum" ve "Sıcak satış yeteneği ile ön plana çıkıyor" cümlelerindeki sıcak kelimesi ilk cümlede negatif polarite ifade ederken ikinci cümlede nötr bir polarite göstermektedir (Pradhan vd., 2016; Karoui vd., 2019; Liu, 2020; Cebeci, 2020). Yapılan çalışmalar, belirli bir alana odaklanan bir duygu sözlüğünün, genel amaçlı bir duygu sözlüğüne kıyasla, hedef alan ile ilgili duyguların daha iyi temsil edildiğini kanıtlamıştır. Genel sözlükler çok iyi tanımlansalar bile olası tüm sektör ve alanları temsil edememektedirler (Taboada vd., 2011; Park vd., 2015;Liu, 2020). Her ne kadar, duygu analizi alanında çok çeşitli metodojiler kullanan farklı çalışmalar mevcut ise de bunların büyük bir kısmı marka imajını, alanda geliştirilmiş mevcut genel sözlükler ve İngilizce kaynaklı olarak ortaya koymaya çalışmışlardır. Oysa İngilizce kaynaklı ve alan bağımsız olarak geliştirilen bu genel sözlükler her sektör ve alana standardize edilememekte ve farklı kültürel alt yapılara ya da farklı bağlamsal faktörlere genellenememektedir. Dolayısıyla sosyal bilimlerin birçok alanında olduğu gibi pazarlama ve marka alanında da analizleri kendi durumsallığında ve anlık olarak inceleyecek yöntemlerin önemi artmıştır (Başfırıncı, 2016). Marka imajı alanında duygu analizinin yüksek performans gösterebilmesi için marka imajı terimlerini kapsayan ve bu terimleri temsil eden duygu yönelimlerini (negatif, pozitif ve nötr) marka bağlamında ele alan bir Türkçe sözlük gerekmektedir. Türkçe sözlük eksikliğinden dolayı doğal dil işleme ve metin madenciliğinde sözlüğe dayalı Türkçe kaynaklı çalışmalar çok sınırlı kalmaktadır.

Bu ihtiyaca dayalı olarak bu çalışmada, alan bağımlı kaynak eksikliği ihtiyacını gidermek hedefi ile marka imajı alanına ait sözlük geliştirme hedeflenmiştir. Bu amaçla şu araştırma sorularına cevap bulunmaya çalışılmıştır: Literatürde marka imajı alanında kullanılan kelimeler nelerdir? Marka imajını karakterize eden duygular ve bu duygulara ait kelimeler hangileridir? Geliştirilen bu sözlük ile firmaların markalarına yönelik imaj belirleme çalışmaları yaparak tüketici duygu ve düşüncelerini zamanında fark etmesi ve rekabet avantajı için gerekli önlemleri zamanında alabilmesi beklenmektedir. Diğer yandan, akademik çalışmalar için Türkçe literatüre bir marka imajı sözlüğü kazandırılması hedeflenmiştir. Marka imajı alanında yapılmış olan bu sözlüğün daha sonraki marka imajı ile ilgili duygu analizi çalışmalarına bir ön hazırlık niteliğinde araştırmacılara katkı sağlaması düşünülmektedir.

\section{Kisitlar}

Duygu analizi çalışmaları günümüzde çoğunlukla sosyal medya mecralarında kullanıcı mesajları, ürün, marka, film, müzik yorumları gibi veri setleri üzerinde yapılmaktadır, sosyal medyanın kendine has bir üslubu, kısaltmaları ve kendine özgü 
bir lisanı vardır. Mesajlardaki karakter sayılarının yetersiz olmasından ötürü çok sayıda kısaltma kullanılmaktadır. Bu durum genellikle ürün, hizmet ve marka yorumları için de geçerlidir. Ayrıca kullanıcılar tarafından yazılan bu yorumlarda Türkçe'nin dil kurallarına uyulmamakta, birçok metinde noktalama işaretleri hiç kullanılmamaktadır. Sonuç olarak duygu analizine konu olacak metinlerden elde edilen yorumlar son derece kirli kelimelerden oluşmaktadır. Bu bağlamda, yapılan sözlük tabanlı duygu analizi çalışmalarında kullanıcıların yazmış olduğu kelimelerin eş değerini bulmak önemli bir kısıt oluşturmaktadır. Ayrıca sözlük tabanlı yaklaşımlarda genellikle doğal dil işleme yöntem ve araçları kullanılmaktadır. İngilizce gibi dünya genelinde yaygın olarak kullanılan popüler dillerde güçlü doğal dil işleme araçları mevcutken Türkçe kaynaklı araçların sınırlı olması da çalışma kısıtlarından biri olarak karşımıza çıkmaktadır. RStudio ortamında Türkçe diline uygun olarak kelime köklerine ayırma yazılımının mevcut olmaması bu çalışmadaki kısıtlar arasında yer almaktadır. Türkçe kaynaklı duygu analizi çalışmalarında bu durum mutlaka göz önüne alınmalıdır. Türkçe gibi yaygın olarak kullanılmayan diğer dillerde duygu analizi yapabilmek için güçlü ve gelişmiş doğal dil işleme yöntem ve araçlarına ihtiyaç duyulmaktadır. Marka imajı boyutlarına spesifik bir sınır çizeceği düşüncesi ile çalışma kapsamında elde edilen marka boyut ve terimlerinin tez literatüründen oluşması araştırmanın son kısıtını oluşturmaktadır.

\section{LITERATÜR ARAŞTIRMASI}

Literatürde duygu analizi bağlamında yapılan sözlük çalışmaları son 10 yıl içerisinde yoğunlaşmıştır. Bu çalışmalardan bazılarına bu kısımda yer verilmektedir.

Hu ve Liu (2004) çalışmalarında, WordNet (Fellbaum,1998) sözlüğünden yararlanarak elde ettiği kelimeleri Sözlük (Lexicon) temelli yöntem ile uygulamıştır. Uyguladığı duygu sözlüğünde, tüketici yorumlarını temel alarak, negatif ve pozitif olarak sınıflandırmıştır. Yöntemin temelinde özellik çıkarım yaklaşımı benimsenerek ürünlerin temel özelliklerini belirlemek amaçlanmıştır. Ürün ile ilgili yorumların duygu polaritesi hesaplanarak ürün özellikleri ile ilgili düşünceler özetlenmiştir.

Ding vd., (2008) çalışmalarında, ürün yorumlarını değerlendirerek bu yorumların duygu polaritelerini negatif, pozitif ve yansız olarak sınıflandırma analizi yapmışlardır. Çalışmanın temel amacı, alan bağımlı olarak ürün yorumlarından elde ettikleri kelimeleri sınıflandırmaktır. Bunun için kelime tabanlı (Lexicon) yöntemi benimsemişlerdir. Yapılan çalışma sonucunda, Duygu Gözlemcisi ismi verdikleri bir uygulama geliştirmişlerdir.

Kouloumpis vd., (2011), Twitter üzerinde yapılan fikir analizinin etkisini de-ğerlendirmek üzere, denetimli makine öğrenmesi yöntemi ile twitter da yer alan negatif, pozitif ve nötr fikirlere odaklanmışlardır. Bu amaçla üç farklı yapıda twitter mesajı toplamışlardır. Bunlardan ikisi olan hastag (HASH) ve emoji (EMOT) yapılarında olan twittleri algoritmalarında eğitmek üzere kullanmışlardır. Modellerini İSİeve işletmesinin manuel (el ile) olarak derecelendirdikleri 4000 tane twit içeren veri seti ile denemişlerdir.

Nielsen (2011), twitter yorumlarından elde ettikleri veri seti üzerinde yeni bir duygu sözlüğü geliştirme çalışması yapmışlardır. AFINN adını verdikleri bu sözlük, 2000'den fazla duygu kelimesi barındırmaktadır. Duygu kelimelerini skor lama yaklaşımı olarak manuel bir yaklaşım benimseyerek, pozitif kelimeleri 1 ile 5 arasında skorlamış, negatif kelimeleri ise -1 ile -5 arasında skorlar vermiştir.

Taboada vd., (2011), Amazon'un Mechanical Turk sözlük hizmetinden faydalanarak haberlerde ve bloglarda yer alan telefon, otel, araba ve benzeri ürün ve hizmetler hakkında yorumları veri seti olarak derlemişlerdir. Bu verileri kullanarak sözlük (Lexicon) tabanlı bir duygu analizi sözlüğü ve duygu sınıflandırma çalışması yapmışlardır. Oluşturmuş oldukları sözlükteki kelimeleri -5 ile +5 arasında manuel olarak skorlar vererek duygu polaritelerini oluşturmuşlardır. Duygu analizi sınıflandırma görevinin yapılması amacıyla SO-CAL adını verdikleri bir uygulama geliştirmişlerdir. Elde edilen 3272 kelimelik sözlügün başarı oranı diğer sözlükler ile karşılaştırıldığında daha yüksek bir performans ile çalıştığını göstermişlerdir.

Xie ve Li (2012), alan bağımsız ve korpus tabanlı bir sözlük geliştirme yaklaşımını benimsemişlerdir. İçerisinde negatif, pozitif ve tarafsız kelime kutuplarını içeren yeni geliştirdikleri sözlüğe ilgili korpus temel alınarak oluşturulduğu için corpusrel adını vermişlerdir. Çalışmalarında ayrıca Tag Sentiment Topic Model (TSTM) adını verdikleri bir de model geliştirmişlerdir. Bu model içerisinde pozitif ve negatif kelimelerin olduğu bir liste yer almaktadır ve her bir negatif pozitif kelime grubu 
kümelere bölünmektedir. Harika, iyi güzel, doğru, süper ve şanslı gibi pozitif görüş ifadeleri pozitif kelimeler kümesini oluşturmakta, kötü, zayıf, maalesef, yanlış, bayağı ve çirkin gibi negatif duygu bildiren kelimeler ise negatif kelimeler kümesini oluşturmaktadır.

Balahur vd., (2012), yapmış oldukları duygu analizi çalışmalarında, duygu polaritesini belirlemeye ek olarak kişilerin hissettikleri duygu durumlarına göre utanma, korku ve kızgınlık olarak sınıflandırmışlardır. Oluşturdukları sözlük için veri setini Appraisal Theory bağlamında oluşturulmuş olan ISEAR (Scherer ve Wallbott, 1997) veri setinden elde etmişlerdir. Elde ettikleri çalışmayı unigram, bigram ve 3-gram özelliklerine göre makine öğrenmesi metotları ile karşılaştırmışlar ve daha başarılı olduğu sonucuna ulaşmışlardır.

Kaya vd., (2012), Türk politika haberleri veri setini kullanarak dört makine öğrenme algoritmasının fikir analizi başarı değerlerini karşılaştırmışlardır. Siyaset ile ilgili veri setini pozitif ve negatif duygular olarak gruplandırarak bir derlem oluşturmuşlardır. Maksimum entropi ve N-gram dil modeli, destek vektör makinesi ve naif bayes sınıflandırma algoritmalarına göre daha başarılı olmuştur. Yapılan duygu analizi sonucunda \%67 ile \%76 oranında başarı sağlamışlardır.

Kang vd., (2012), sözlük tabanlı (Lexicon) ve değişik makine öğrenimi metotlarını kullanarak duygu analizi çalışması gerçekleştirmişlerdir. Bu çalışmanın temel katkısı, yazarlar özel bir alan ile ilgili sözlük geliştirme deneyimi elde etmişlerdir. Sadece restoran yorumları ile ilgili veri seti üzerinde duygu terimleri sözlügüü oluşturmuşlardır. Restoran yorumlarını derecelendirerek, tekli ve çoklu kelimeleri de derecelendirme kapsamına dâhil etmişlerdir. Yapılan çalışmada sonuç olarak, standart duygu terimleri sözlüğü ile yeni geliştirdikleri restoran duygu sözlüğünü çeşitli makine öğrenmesi algoritmaları ile karşılaştırdıklarında daha iyi sonuçlar alabilmek için testlerini sürdürmüşlerdir.

Robaldo ve Caro (2012), farklı bir uygulamaya odaklanarak XML dosya uzantılı bir fikir madenciliği uygulaması geliştirmişler. $\mathrm{Bu}$ amaçla fikir madenciliği-makine öğrenimi (ML) adında bir uygulama geliştirerek, restoran yorumlarını kullanarak alan bağımlı ve alan bağımsız bir sorgulama prosesi elde etmişlerdir.

Boldrini vd., (2012), doküman kelime ve cümle gibi farklı seviyelerdeki duygu analizi görevleri için öznel etiketleme uygulaması geliştirmişlerdir. Bu amaçla, üç başlık ve İspanyolca, İngilizce ve İtalyanca dillerinde olmak üzere üç farklı dilde bloglardan veri toplamışlardır. Topladıkları 270.000 yorumu EmotiBlog adında bir korpusta toplayarak duygu sınıflandırması ve duygu tarama uygulaması geliştirmişlerdir. Bu EmotiBlog korpusunu daha sonra ISEAR veri seti ile test etmişler ve yeterli bir başarı oranı yakalamışlardır.

Steinberger vd., (2012), yeni bir sözlük kaynağ geliştirme alanına odaklanmışlardır. Araştırmalarında yarı otomatik bir yaklaşım benimseyerek birçok farklı dilde duygu sözlüğü geliştirmeyi amaçlamışlardır. İlk olarak haber verilerini toplayarak iki dilde bir sözlük geliştirmişler ve daha sonra bu sözlüğü otomatik olarak üçüncü bir dile çevirme uygulaması geliştirmişlerdir. Kendi yaptıkları üçlü kelime listesi otomatik makine çevrimi listesi ile karşılaştırarak geçerliliğini test etmişlerdir.

Kaufmann (2012), ise iki dilde var olan bir kelime listesini, benzer morfolojik özellikler gösteren üçüncü dillere otomatik çevriminin yapılabileceği bir sistem amaçlamıştır. Bunun için, istatiksel bir makine dönüştürücü sistemi kullanarak, oluşturduğu korpustaki kelime listelerini taratıp bu dil ile diğer diller arası benzerlik ilişkilerini keşfederek otomatik olarak çevrim yapabilen JMaxAling uygulamasını geliştirmiştir. İngilizce-İspanyolca ve İngilizce-Arapça dillerine otomatik kelime tercüme sürecinde makine öğrenme algoritmalarından yararlanmıştır.

Akbaş (2012), Türk twitlerinden elde ettiği verilerden, varlık görüş fikir madenciliği çalışmasına odaklanmışlardır. El ile hazırladıkları duygu kelime listesini kullanarak otomatik olarak yeni bir kelime seçme algoritması geliştirmiştir.

Şimşek ve Özdemir (2012), veri madenciliği tekniklerini kullanarak Türk twitter veri setini inceleyerek Türkiye tweet〉leri ile Türkiye borsa endeksi arasında bir ilişki olup olmadığını görmek için bir duygu analizi çalışması yapmışlardır. Bu duygu analizi çalışmasında Amazon'un Mechanical Turk hizmetinden yararlanarak 113 tane mutluluk ve mutsuzluk duygusunu ifade eden duygu kelimeleri ile bir Türkçe sözlük oluşturarak, twitter mesajlarını sınıflandırmışlardır. Sonuç olarak Türk tweet verileri ile Türkiye borsa endeksi arasında \%45 oranında ilişki olduğunu saptamışlardır. 
Sevindi (2013), Baccianella vd., (2010), tarafından geliştirilen SentiWordNet sözlüğünü Türkçeye çevirmişlerdir. Türkçeye tercüme ettikleri duygu sözlüğ̈̈ kaynağında 12697 tane kelime yer almaktadır.

Vural vd. (2013), yine benzer bir çalışma yaparak, Thelwall, vd., (2010)'nn geliştirdikleri SentiStrength duygu analizi kütüphanesini Türkçeye çevirerek Türkçe bir duygu sözlüğü kaynağı hedeflemişlerdir. Bunun için beyaz perde.com adresinden film yorumlarını toplayarak, sözlük tabanlı duygu sınıflandırma analizi yaparak \%76 oranında başarı elde etmişlerdir.

Aytekin (2013), Türkçe blog sitelerinde beyaz eşya, teknoloji, ufak ev aletleri, ısıtıcı ve klima ürünlerine ait yorumlar üzerinde duygu polaritesinin yönünü tespit çalışması yapmıştır. Çalışmada sözlük tabanlı yaklaşım ile makine öğrenmesi yaklaşımlarından yararlanarak yarı-denetimli bir teknik benimsemiştir. İngilizce 'de hazırlanmış negatif ve pozitif anlamlar içeren 700 kelimelik bir sözlüğü Türkçe 'ye uyarlayarak, çalışmada pozitif yorumlarda $\% 72$, negatif yorumlarda $\% 73$ başarı oranı elde etmiştir.

Kang ve Park (2014), tüketici memnuniyeti analizi kapsamında, müşterilerin mobil servisler konusundaki yorumlarından hareketle duygu analizi çalışması yapmışlardır. Manuel olarak düzenledikleri duygu ifadesi belirten kelimeleri -2 ile +2 arasında değişen skorlar vererek, duygu yönelimlerinin polaritesini belirlemişlerdir.

Dehkharghani vd., (2015)'te yapmış oldukları çalışmada, Türk dili duygu analizi çalışmaları için yeni bir sözlük geliştirmişlerdir. Yeni geliştirdikleri sözlük oluşumunda yarı otomatik bir yöntem benimsemişlerdir. Geliştirmiş oldukları sözlüğün içerisinde, Türk WordNet (Bilgin vd., 2004) sözlüğünde yer alan 14795 tane eş anlamlı kelime yer almaktadır. Duygu kelime skorlarının bulunduğu ve SentiTurkNet adını verdikleri sözlük literatürde ilk duygu değeri içeren sözlük kaynağı olarak yer almaktadır.

Park vd., (2015), duygu terimleri sözlügü geliştirme ile ilgili bir çalışma amaçlamışlardır. Alana özgü bir duyarlılık sözlüğü oluşturma maliyeti, daha geniş ve pratik uygulamalarını engellemektedir. Bu zorluğu telafi etmek için, ilgili terimleri dikkatli bir şekilde seçerek etki alanına özgü bir duyarlılık sözlüğü çıkarmayı önermişlerdir. Önerdikleri bu yöntem ile daha önce Baccianella et al. (2010) geliştirdikleri duygu terimler sözlüğü SentiWord ile performansını kıyaslamışlardır.

Al-Ayyoub vd., (2015), veri sözlüğü tabanlı yaklaşımı benimseyerek Arapça dilinde yeni bir sözlük oluşturma çalışması gerçekleştirmişlerdir. Arapça kelime köklerinin yer aldığı Abuaiadh (2011) veri setini kullanarak bu kelimeleri İngilizce olarak tercüme etmişler ve kelime değerlerini çevrimiçi olarak sentiment140.com adresinden belirlemişlerdir. Genişletilmiş bir sözlük oluşturmak için ise Aljazeera.net adresindeki Arap haber sitesinden elde etmişlerdir. 120.000 kelimeye dayalı olarak geniş bir Arapça sözlüğü oluşturmuşlardır.

Khan vd., (2016), Çevrim içi sinema yorumları, ürün yorumları ve müşteri yo-rumlarından elde ettikleri veri setleri üzerinde yapmış oldukları çalışmada denetimli makine öğrenmesi metodu ile duygu analizi çalışması gerçekleştirmişlerdir. Bir İngilizce duygu terimleri sözlüğü olan WordNet servisinin daha iyi performans sağlaması amacıyla WordNet sözlüğü temel alınarak yeni bir duygu terimleri sözlüğü geliştirmişlerdir. Duygu kutbu sınıflandırma yaklaşımında eSAP adını verdikleri bir uygulama geliştirmişlerdir. Sonuç olarak yeni geliştirdikleri duygu sözlüğünün WordNet duygu sözlüğünün performansını $\% 13,4$ oranında artırdığını göstermişlerdir.

Öztürk ve Ayvaz (2018), çalışmalarında R programlama dili ile twitter kullanıcıların Suriye mülteci krizi hakkındaki görüş ve yorumlarını belirlemek üzere twitter sosyal mecrasından "Suriye", "Suriyeli", "Savaş" ve "Mülteci” kavramlarının geçtiği twitleri toplayarak kelime sıklıklarını ve duygu polaritelerini belirlemeye çalışmışlardır. Çalışmalarında 5000 kelimelik bir sözlük geliştirerek -5 ile +5 arasında manuel olarak skorlar vererek duygu yönlerini saptamışlardır.

Yukarıdaki çalışmalardan da görüldüğü üzere duygu sözlüğü geliştirme çalışmalarında marka imajı alanına özgü bir araştırma yapılmamıştır. Yapılan çalışmalar genellikle İngilizce dilindedir. Ayrıca Türkçe çalışmalar çok sınırlı ve genel sözlük oluşturma kapsamında ele alınmıştır. Bu çalışmanın önceki çalışmalardan farklı olarak marka imajına özgü olması bakımından literatüre katkı sağlaması beklenmektedir.

\section{YÖNTEM}

Bu çalışmada, literatürde marka imajı alanında kullanılan kelimeler neler olduğu, marka imajını karakterize eden duygular ve bu duygulara ait kelimelerin nelerden oluştuğu ile ilgili sorulara yanıt aranmıştır. Bu bağlamda, $R$ yazılım aracı kullanılarak marka imajı belirlemeye yönelik duygu analizi için gerekli olan bir Türkçe sözlük geliştirme süreci hedeflenmiştir. 
Duygu sınıflandırma teknikleri genel olarak makine öğrenmesi yaklaşımı, sözlük tabanlı (Lexicon Based) yaklaşım ve hibrid yaklaşım olmak üzere üç temel kategoride ele alınmaktadır. Bu çalışmada, duygu sınıflandırma tekniklerinden olan sözlük (Lexicon) tabanlı derlem yaklaşımı benimsenmiştir. Bunun temel sebebi, özel alanlı sözlük çalışmalarında derlem tabanlı yaklaşımın daha iyi performans göstermesi (Liu, 2020) ve Türkçe olarak herhangi bir yazılım ve marka imajı bağlamında özel alanlı bir sözlük geliştirilmemiş olmasıdır. Derlem (Corpus ) yaklaşım, özel alan duygu analizi araştırmalarında, duygu yönü belirleme ve duygu terimleri bulma probleminin çözümünde kullanılmaktadır (Liu, 2020; Medhat vd., 2014). Ayrıca, çok sayıda araştırmacının (Stone vd., 1966 akt. Taboada vd., 2011; Hatziassilloglou ve McKeown, 1997; Tong, 2001; Yi vd., 2003; Hu ve Lui, 2004;Nigam ve Hurst, 2004; Wiebe vd., 2005; Esuli ve Sabastiani,2006; Boiy vd., 2007; Taboada vd., 2011 ve Abdul-Mageed, vd., 2011, 2012) çalışmalarında olduğu gibi duygu etiketleme yaklaşımı olarak ise manuel yaklaşım benimsenmiştir. Teknik alt yapı gerektirmemesi ve daha istikrarlı bir etiketleme imkânı sunarak doğruluğu en iyi yöntemlerden biri olması sebebi ile tercih edilmiştir (Hu ve Liu, 2004; Wiebe vd., 2005; Esuli ve Sabastiani, 2006; Boiy vd., 2007).

Yapılan çalışmalarda, makine öğrenimine dayalı istatiksel yöntemlerin genellikle belli bir alanda yüksek başarı oranı elde ettiği fakat alan değiştirildiğinde, kullanılan makine öğrenimi sınıflandırma algoritmaları aynı olsa dahi başarı performansının düştüğü, yeni alan kelimelerine yeteri kadar adapte olamadığı görülmüştür (Aue ve Gamon 2005; Chaovalit ve Zhou 2005; Kennedy ve Inkpen 2006; Boiy vd., 2007; Barlett ve Albright 2008; Tabaoda vd., 2011; Park vd., 2015).

Türkiye'de duygu analizi çalışmaları çoğunlukla mühendislik temelli araştırmacılar tarafından makine öğrenimi ile sınıflandırma algoritmaları (Naif Bayesian, Destek Vektör Makinesi vb.) geliştirilmeye yönelik olmaktadır. Dolayısı ile sosyal bilimcilerin ya da işletmelerde çalışanların da duygu analizi yapabilmesi için, algoritmik alt yapıya sahip olmaları gerekmektedir. Bu çalışmada sosyal bilimcilerin de duygu analizi tekniğini kullanabilmeleri için göreceli olarak uygulaması daha basit ve teknik alt yapı gerektirmeyen bir duygu analizi yöntemi kullanılmıştır.

\section{BULGULAR}

$\mathrm{Bu}$ çalışmanın analizleri sekiz aşamada gerçekleştirilmiştir. Marka imajı alanına özgü metinler veri seti olarak bir derlem de listelenmiştir. Listelenen bu sözcüklerin kelime düzeyinde duygu kutupları belirlenmiş, bu duygulara manuel skorlar atanarak bir sözlük geliştirilmiştir. Şekil 1' deki sözlük geliştirme şemasında çalışmadaki adımların süreçleri özetlenmiştir. Bu süreç aşağıda detaylı olarak anlatılmıştır.

\subsection{Veri Çıkarımı (Data Extraction) Adımı}

Türkiye'de marka imajı ile ilgili yapılmış olan 113 tez çalışması Yüksek Öğrenim Kurumu (YÖK) web sitesinden 1998-2019 tarihleri arasında taranarak indirildikten sonra bir metin dosyası olarak kaydedilmiştir. Marka imajı ile ilgili yapılan çalışmalarda, büyük oranda tezlerden yararlanılmasının nedeni, tanımların ve marka imajı boyutlarının ve ilişkili kavramların daha detaylı olarak incelenmiş olmasıdır.Marka imajı ile ilgili yapılan çalışmalarda büyük oranda tezlerden yararlanılmasının nedeni, marka imajı ile ilgili kavramlara literatür incelemesi sonucu toplu olarak ulaşabilme imkanına sahip olunması ve tezlerin marka imajı ile ilgili spesifik bir sınır çizmesi nedeniyle tez metinleri incelenmiştir

\subsection{Derlem (Corpus) Oluşturma Adımı}

YÖK, tez sayfasından elde edilen veriler, metin dosyası olarak kaydedilmiş ve marka imajı literatür korpusu olarak oluşturulmuştur. Kayıt edilen marka imajına ait korpus RStudio platformuna çağrılmış ve okutulmuştur. Daha sonra programa gerekli dosya ve paketler yüklenerek, R programı içerisindeki doğal dil işleme fonksiyonu ile metin ön işleme sürecine tabi tutulmuştur.

\subsection{Veri Çerçevesi Oluşturma (Data Frame) Adımı}

$\mathrm{Bu}$ adım, RStudio platformunda analiz sürecine tabi tutulmak istenen dosyaların R formatına dönüştürülmesi için yapılan kayıt adımını oluşturmaktadır. Böylece her dosyanın içeriği satır ve sütunlardan oluşan bir tablo özelliğine dönüştürülmüştür. Elde edilen toplam kelime sayısı 1.738 .596 adet olarak gözlemlenmiştir. 


\section{4. $R$ ile Metin Ön İşleme (Pre- Processing) Adımı}

Kolay anlaşılır ve uygulanabilir bir ara yüze sahip olması bakımından hem de büyük hacimli veri setlerinde gösterdiği performans ve metin madenciliği alanında etkin sonuçlar sağlaması sebebi ile RStudio analiz yazılımı tercih edilmiştir. R programında yer alan “tm”, “tidytext” ve “dplyr” kütüphaneleri metin ön işleme sürecinde kullanılmış "wordcloud2” ve "ggplot2” kütüphanelerinden ise metin görselleştirme adımlarında yararlanılmıştır.

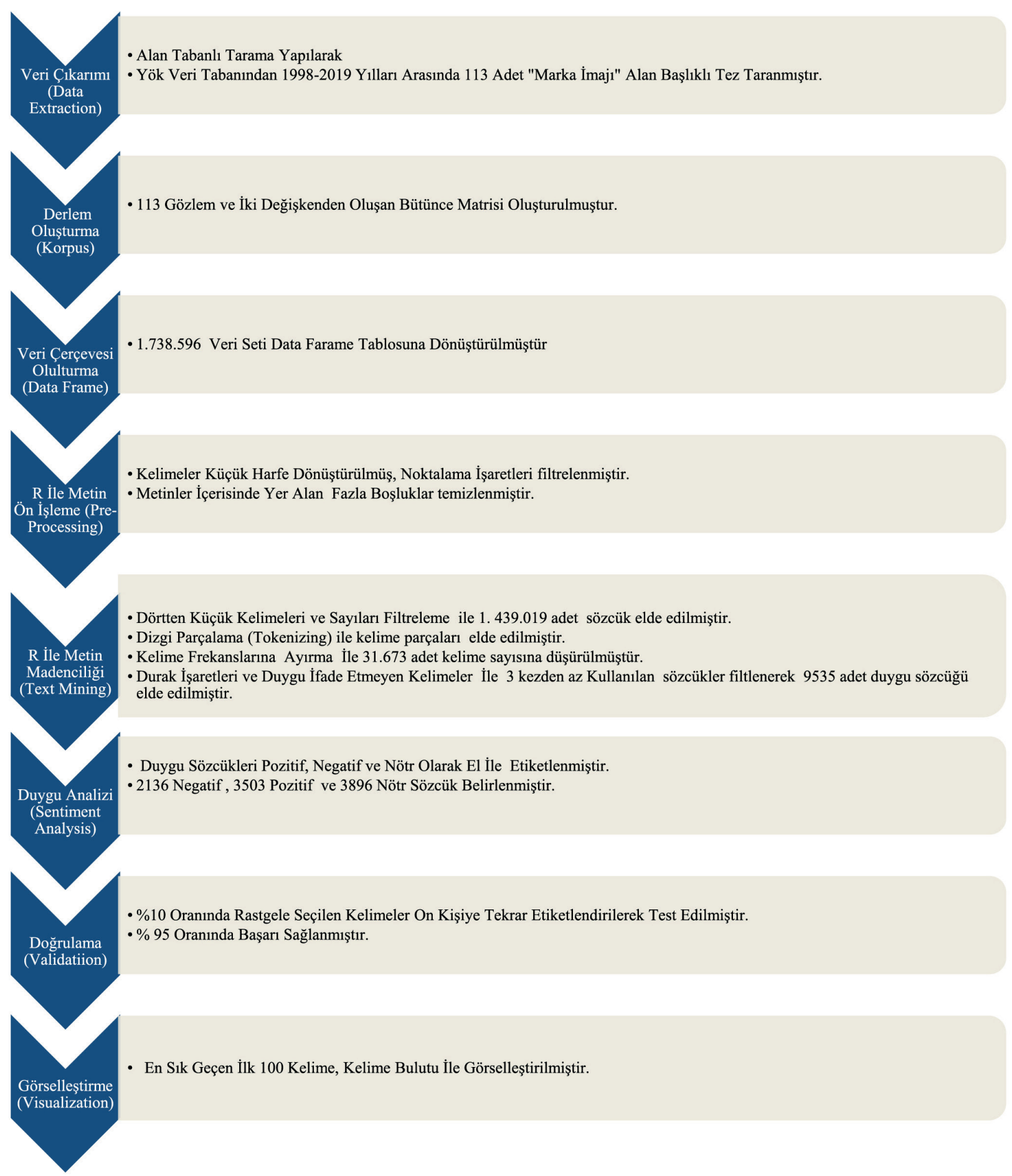

Şekil 1. Sözlük Geliştirme Şemas1 


\section{Her Sözcüğü Küçük Harfe Çevirme ve Fazla Boşlukları Temizleme İşlemi}

Aşağıda Tablo 1'de örnek veri metni, içerisinde büyük harfler içermektedir. Doğal dil işleme fonksiyonu ile büyük harfle yazılmış kelimelerin hepsi küçük harfe dönüştürülmüş ve gereksiz boşluklardan arındırılmış ve Tablo 2'de gösterilmiştir. Böylece tüm kelimeler büyük küçük harfe karşı duyarsızlaştırılmıştır. Kelimeler arasında birden fazla boşluğun bulunması kelime frekans işlemlerinde bir kelime olarak algılanmaktadır ve bu da istenmeyen bir durumdur.

Tablo 1

Büyük Harflerin ve Fazla Boşlukların Yer Aldı̆̆ı Bir Paragraf Örneği

Kişilerle ilgili imajda; iyi bir kişidir, bilgili bir kişidir ve eğlenceli bir kişidir gibi yargılarda bulunulmaktadır. Kuruluşlarla ilgili olarak gelişecek olan imajda ise; işletmenin donanımı, tutumu, iletişim biçimi, kurumsal dizaynı etkili olmaktadır ve genel olarak imaj konusunda başlıca üç öğeden söz edilmektedir. Bunlar; bilgilenme düzeyi, sahip olunan yargılar ve sunulan olanaklarla hizmetler olup, bu öğeler aşağıdaki başlıklar altında açıklanmaktadır( ....; (Tolongüç, 1992

Tablo 2

Küçük Harfe Çevrilmiş ve Gereksiz Boşluklardan Temizlenmiş Paragraf

kişilerle ilgili imajda; iyi bir kişidir, bilgili bir kişidir ve eğlenceli bir kişidir gibi yargılarda bulunulmaktadır. kuruluşlarla ilgili olarak gelişecek olan imajda ise; işletmenin donanımı, tutumu, iletişim biçimi, kurumsal dizaynı etkili olmaktadır ve genel olarak imaj konusunda başlıca üç öğeden söz edilmektedir. bunlar; bilgilenme düzeyi, sahip olunan yargılar ve sunulan olanaklarla hizmetler olup, bu öğeler aşağıdaki başlıklar altında açıklanmaktadır (tolongüç, $\ldots ;(1992$

\section{Noktalama İşaretlerinden Arındırma İşlemi}

Tablo 3' teki örnek metinde yer alan “.”, “,”, “?”, “!”, “_,”, “)”, “(” gibi noktalama işaretleri, veri seti içerisinden silinerek veriler daha sade hale dönüştürülmüştür.

Tablo 3

Noktalama Işsaretleri Arınmış paragraf Örneği

kişilerle ilgili imajda iyi bir kişidir bilgili bir kişidir ve eğlenceli bir kişidir gibi yargılarda bulunulmaktadır kuruluşlarla ilgili olarak gelişecek olan imajda ise işletmenin donanımı tutumu iletişim biçimi kurumsal dizaynı etkili olmaktadır ve genel olarak imaj konusunda başlıca üç öğeden söz edilmektedir bunlar bilgilenme düzeyi sahip olunan yargılar ve sunulan olanaklarla hizmetler olup bu öğeler aşağıdaki başlıklar altında açıklanmaktadır tolongüç 1992

\subsection{R ile Metin Madenciliği (Text Mining) Adımı}

\section{Dörtten Ten Küçük Olan Sözcüklerin ve Sayıların Veri Setinden Atılması İşlemi}

Veri seti içinde dört harften küçük kelimelerin (yön, yan, son, söz vb.) yoğunlukla yer alması ve bu kelimelerin analiz bulgularına herhangi bir etkisinin olmaması sebebi ile ön temizlemeye tabi tutulmuştur. Harf sayısı dörtten küçük sözcükler ve metinlerde yer alan sayıların ön temizlemeye tabi tutulmasından sonra toplam kelime sayısı 1.439.019’ a indirgenmiştir.. Dörtten küçük kelimelerin içerisinde yer alan duygu ifade eden kelimeler (iyi, hoş,acı,adi,boş,yok vb.) sözlük başarısına olumsuz etki etmemesi bakımından taranarak tekrar verisetine eklenmiştir.

Tablo 4

Dörtten Küçük Kelimelerin ve Sayıların Yer Aldığı Örnek Metin

kimlik kavramı; insanlara yön, amaç ve anlam sağlayarak hizmet etmektedir. Markalarda da aynı durum söz konusudur. Açık, net ve güçlü bir kimlikten yoksun olan bir marka dümensiz bir gemiye benzemektedir (Joachımsthaler ve Aaker,1999:9). Bir insan için, yaşam felsefesinde ana değerlerinin ne olduğu, hayatta hangi anlam için var olduğu, diğer insanlar tarafından nasıl algılanmak istediği, hangi ayırt edici kişilik özelliklerini yansıtmak istediği ve hayatındaki en önemli ilişkilerinin kimlerle olduğu konuları ne kadar önemliyse, marka kimliği de o işletme ve sunduğu mal veya hizmete yön, amaç ve (anlam kazandırması bakımından o derece önemlidir. (Aaker,1996:304

Tablo 5

Dörtten Küçük Kelimelerin ve Saylların Temizlendiği Örnek Metin

kimlik kavramı; insanlara, amaç anlam sağlayarak hizmet etmektedir. Markalarda aynı durum konusudur. Açık, güçlü kimlikten yoksun olan marka dümensiz gemiye benzemektedir (Joachımsthaler Aaker,). insan için, yaşam felsefesinde değerlerinin olduğu, hayatta hangi anlam için olduğu, diğer insanlar tarafından nasıl algılanmak istediği, hangi ayırt edici kişilik özelliklerini yansıtmak istediği hayatındaki önemli ilişkilerinin kimlerle olduğu konuları kadar .önemliyse, marka kimliği işletme sunduğu veya hizmete amaç anlam kazandırması bakımından derece önemlidir

\section{Dizgi Parçalama İşlemi}

Dizgi Parçalama (Tokenize): Dizgi parçalama işlemi metin içerisindeki paragrafları kelime parçalarına ayırmakta kullanılır. Bu sayede veriyi parçalara ayırıp anlamlı bilgiler elde etmek hedeflenir. Bu işlem ile metin dosyasında bulunan her kelime 
ayrı nesnelere dönüştürülmüş olur. Örneğin "Açık, net ve güçlü bir kimlikten yoksun olan bir marka dümensiz bir gemiye benzemektedir" cümlesi parçalama işleminden sonra "Açık”, "net” “ve” "güçlü” "bir” "kimlikten” “yoksun” "olan” "bir" "marka" "dümensiz" "bir" "gemiye" "benzemektedir" şeklinde 15 farklı nesne haline gelir.

\section{Kelime Frekanslarının Belirlenmesi İşlemi}

Marka imajına ait tez çalışmaları içerisinde bulunan kelimeler sıklıklarına göre büyükten küçüğe doğru sıralanarak 31.673 en sık geçen nesneler olarak sıralanmıştır.

\section{Durak (Stopword) Kelimelerinin ve Yargı Belirtmeyen Kelimelerin Temizlenmesi}

Korpusta yer alan veri seti son olarak kontrol edilerek içerisindeki değer yargısı ifade etmeyen kelimelerden ve durak kelimelerinden arındırılır. Durak kelimeleri bağlaçlar zaman zarfları, yer yön zarfları, soru zarfları, kişi zamirleri ve bağlaçları kapsar. Durak sözcüklerini temizleme süreci İngilizce R'ın NLP kütüphanelerinde bir fonksiyon filter (stopword) olarak yer alır. Fakat Türkçe dilbilgisi için R’ da tanımlı bir paket yoktur. Aşağıda örneği verilmiş durma sözcükleri korpustan çıkarılmak üzere R programına gereksiz kelimeler vektörü oluşturularak Türkçe olarak tanıtılmıştır. Daha sonra filtreleme fonksiyonu ile işleme sokularak, bu gereksiz kelimeler korpustan atılmıştır. Yukarıdaki metinde geçen örnek durak kelimeleri; aslında, bir, biz, üç, bunlar, bu, gibi, ise vb. kelimelerden oluşmaktadır. Tablo 7 ile veriden çıkartılan durak kelimeleri ve gereksiz kelimeler örneklendirilmiştir.

Tablo 6

Durak Kelimeleri ve Yargı Belirtmeyen Kelimeleri İçeren Paragraf Örneği

reklamcılık faaliyetlerini sürdüren ülkede global fazla yerel markanın marka değerini ölçen, young and rubicam gibi bir(y\&r).........göre markanın yararı "başarı" ise, marka kişiliği "başarılı" veya "kendinden emin” olarak ifade edilir. Bunun yanı sıra markalar, seçkin, uzman, güvenilir, eğlenceli, sportif, esprili gibi özelliklerle de çağrıştırılabilir

Gereksiz kelimeler listesinde yer alan durak kelimeleri ve yargı belirtmeyen kelimeler yorumlarda veya görüşlerde zarf ve sıfatların aksine herhangi bir değer yargısına sahip değildirler.

Tablo 7

Gereksiz Kelimeler Vektörü

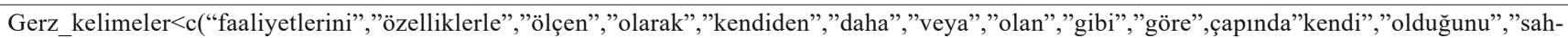

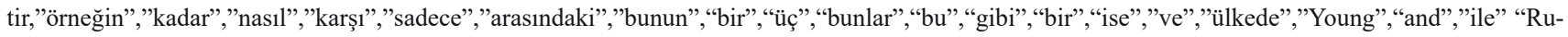
(..... "bicam","aaker","edilir","markanın","yanı","sıra","de

Tablo 8

Durak Kelimeleri ve Yargı Belirtmeyen Kelimelerin Temizlenmiş Örneği

reklamcılık sürdüren global fazla yerel marka değerini yararı başarı marka kişiliği başarılı kendinden emin ifade markalar seçkin uzman güvenilir eğlenceli "sportif esprili çağrıştırılabilir

Türkçenin yapısal özelliklerini ve sosyal medyadaki yazım özelliklerini dikkate alarak varlık yokluk (-l1, -li, -sız, -siz) ekleri ve olumsuzluk bildiren ekler (-me, -ma) filtreleme aşamasında kaldırılmadi. Dilbilimsel kategoride olan "isim”, "fiill”, “sıfat”, “edat", “zamir”, “zarf”, "bağlaç” ve “ünlem” gibi yapılardan yargı bildiren özellikteki "isim”, “fiill”, "sıfat”, ve "zarf” yapıları çekimleri ile birlikte sözlüğe dâhil edildi. Bir kelimenin benzer anlama sahip birçok biçimi olabilir örneğin, "gitmek”, "gittim", "gidiyorum” gibi kelimeler aslında aynı anlama sahiptir. Bu nedenle metinlerdeki ekler atılmadan sözlüğe dâhil edilmiştir. Tablo 9' da örnek olarak gösterilmiştir.

Tablo 9

Ön Işslemden Geçmiş Marka İmajı Karpusundaki Her bir Terimin Kelime Kelime Ayrılmış Örneği

\begin{tabular}{lccc}
\hline Sözcük & Sözcük Yapısı & Sözcük & Sözcük Yapısı \\
\hline iyice & Sifat & iyileştirmeler & İsim \\
iyileşmeme & Fiil & İyilik & İsim \\
iyidir & Sifat & İzin & İsim \\
iyileşmek & Fiil & izinsiz & Sifat \\
iyileştirme & İsim & izinli & Sifat \\
\hline
\end{tabular}


Türkçe olarak yazılmış olan 113 “marka imajı” tez başlığı içerisinden elde edilen toplam kelime sayısı 1.738 .596 olarak bulunmuş ve metin madenciliği veri ön temizleme aşaması ile temizlenerek 1.439.019 adet kelime ye indirgenmiştir. Elde edilen bu kelime kümeleri yabancı kelime, sayı, boşluk gibi duygu ifade etmeyen içeriklerden temizlenerek ön işlemden geçirilmiştir. Frekanslarına ayrılan toplam kelime sayısı 31.673'e indirgenerek yargı belirtmeyen gereksiz kelimelerden arındırılması ve frekans değerleri 3'den az olan kelimelerin elenmesi ile birlikte 9535 adet duygu ifadesine ulaşılmıştır. Şekil 2 ile kelime sayıları görselleştirilmiştir. Kirli ve gürültülü veriler filtrelenmiş ve temizlenmiş olarak frekanslarına ayrılmıştır. İlk 100 kavram görselleştirilmiştir. Bu kelimeler içerisinde en çok geçen 8749 adet sorumluluk, 8286 adet kaliteli,7861 adet güvenilir gibi sıfat ve kelimeler elde edilmiştir. Tablo 10'da örnek olarak gösterilmiştir.

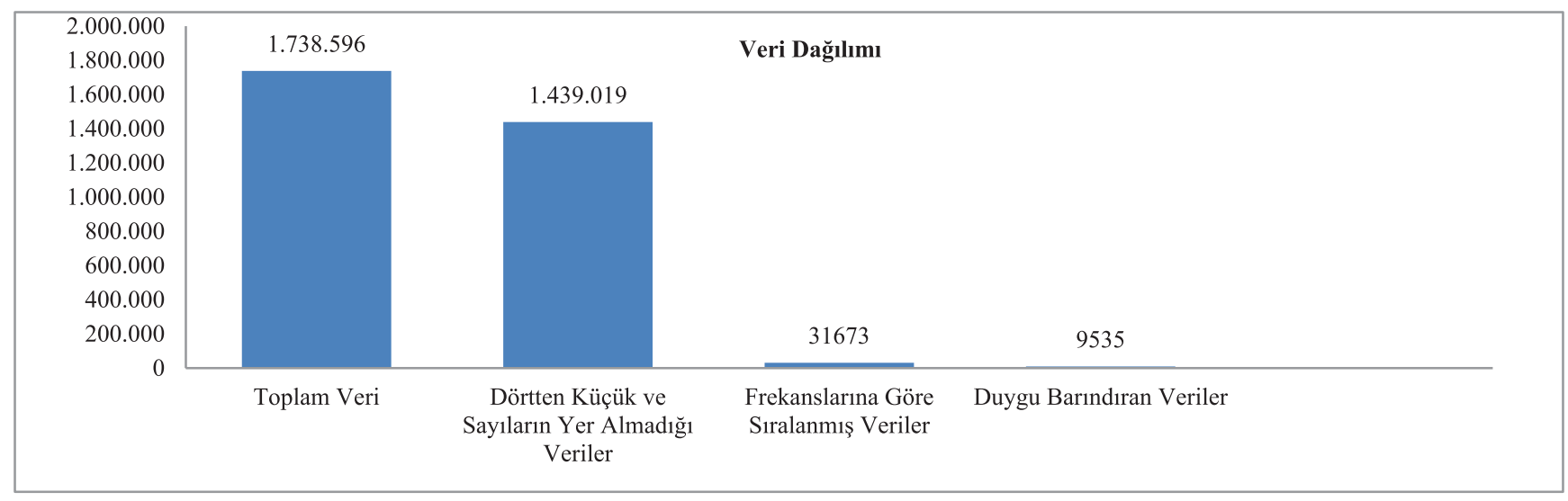

Şekil 2. Ön İşlemden Geçirilen Verilerin Dağılım Grafiği

\begin{tabular}{|c|c|c|c|}
\hline \multicolumn{4}{|c|}{ En sık Geçen Kelime Örneği } \\
\hline Kelime & Sıklık & Kelime & Sıklık \\
\hline Sorumluluk & 8749 & Çekici & 2532 \\
\hline Kaliteli & 8286 & $\ddot{U} n l \ddot{u}$ & 2437 \\
\hline Güvenilir & 7861 & Duyarlıdır & 2381 \\
\hline Duygusal & 7465 & Değer & 2309 \\
\hline Tanınmış & 7330 & Güven & 2024 \\
\hline Tavsiye & 6885 & $\dot{I} y i$ & 2146 \\
\hline Yüksek & 6870 & $\ddot{U} r \ddot{u} n$ & 2068 \\
\hline Moda & 6423 & Başarılı & 2024 \\
\hline Yenilikçi & 6314 & Güvenilirlik & 1997 \\
\hline Saldırgan & 6266 & Modern & 1790 \\
\hline$\ddot{U} s t u ̈ n$ & 6123 & Verici & 1788 \\
\hline
\end{tabular}

\subsection{Duygu Analizi (Sentiment Analysis)}

Kelimelere ayrılmış ve ön işlemden geçirilerek temizlenmiş tüm veri setindeki kelimelere, negatif, pozitif ve nötr olacak şekilde el ile etiketlendirilerek duygu sınıflandırması yapılmıştır. Negatif kelimeler "-1 " skoru ile pozitif kelimeler “+1" skoru ile yansız kelimeler ise "0" olarak etiketlenmiştir. Olumsuzluk bildiren ve kelimelerden sonra gelen "yoktur" ve "değil" gibi kelimeler negatif olarak etiketlenmiştir. Örneğin marka imajı alanı bağlamında; acayip kelimesi negatif bir anlam ifade etmektedir. Bu kelimenin türevleri de negatif bir anlam içermektedir. Örneğin yorumlarda acayip kelimesinin dışında acayiplik ve acayipçe kelimelerinin geçtiği yorumlar olabilmektedir. Bunun gibi türemiş kelimeler de dikkate alınarak duygu listesine eklenerek skorlanmıştır. 
Tablo 11

Negatif Olarak Etiketlenen Kelime Grupları Örneği

\begin{tabular}{lcc}
\hline Kelime & Skor & Duygu Yönü \\
\hline acayip & -1 & negatif \\
acayiplik & -1 & negatif \\
acayipçe & -1 & negatif \\
\hline
\end{tabular}

Tablo 12

Nötr Olarak Etiketlenen Kelime Grupları Örneği

\begin{tabular}{lcc}
\hline Kelime & Skor & Duygu Yönü \\
\hline açan & 0 & nötr \\
açar & 0 & Nötr \\
açarak & 0 & Nötr \\
açarken & 0 & Nötr \\
\hline
\end{tabular}

Tablo 13

Pozitif Olarak Etiketlenen Kelime Grupları Örneği

\begin{tabular}{lcc}
\hline Kelime & Skor & Duygu Yönü \\
\hline ahlaki & 1 & pozitif \\
ahlakidir & 1 & pozitif \\
ahlakli & 1 & pozitif \\
ahlakli & 1 & pozitif \\
\hline
\end{tabular}

Skorlamaya tabi tutulan 9535 adet kelimenin duygu sınıflarına (polarite) göre ayrılmışs sılıkları Şekil 3'de görselleştirilmiştir.

Yapılan sözlük çalışması sonucunda 2136 adet olumsuz sözcük, 3896 adet olumlu sözcük ve 3503 adet yön belirtmeyen sözcük elde edilmiş̧tir. Duygu yönlerine göre marka imajı alanı bağlamında taranan tezlerde en sık geçen ilk 100 kelime ve bu kelimelerin duygu yönleri de Tablo 14 ile gösterilmiştir.

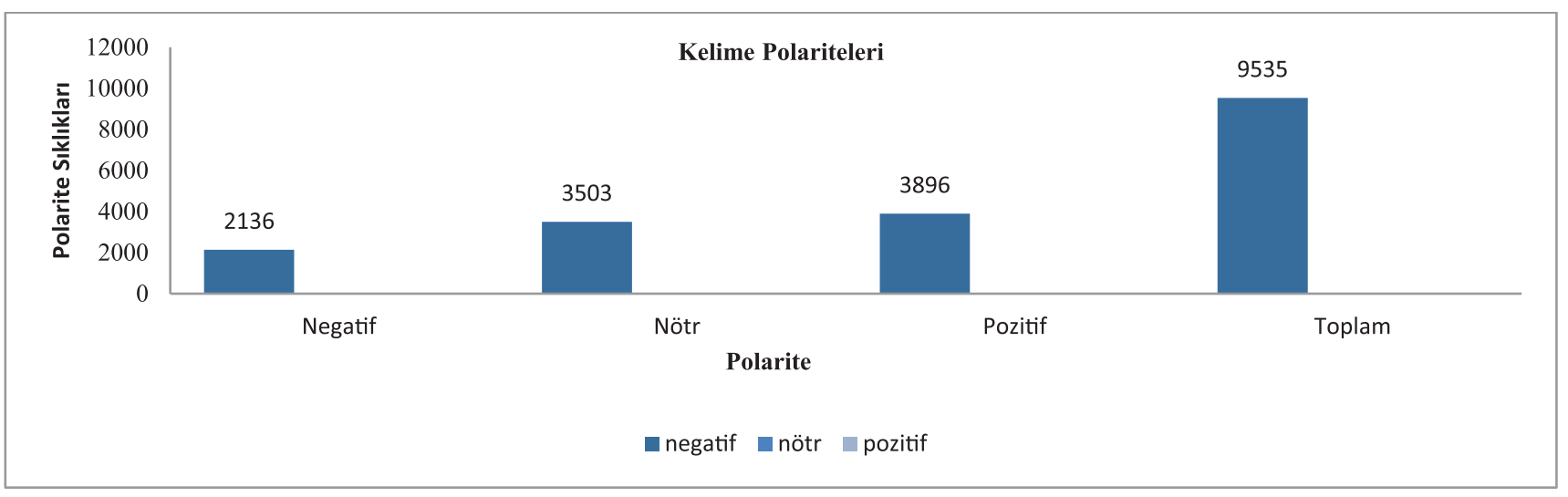

Şekil 3. Marka İmajı Sözlük Polariteleri Grafiği 
Tablo 14

Duygu Sinıfina Göre En Sık Geçen İk 100 Kelime Tablosu

\begin{tabular}{|c|c|c|c|c|c|c|c|c|}
\hline Kelime & Sıklık & $\begin{array}{c}\text { Duygu } \\
\text { Yönü }\end{array}$ & Kelime & Sıklık & $\begin{array}{c}\text { Duygu } \\
\text { Yönü }\end{array}$ & Kelime & Sıklık & Duygu Yönü \\
\hline saldırgan & 5211 & Negatif & olmalı & 63 & Negatif & sinirlı & 20 & Negatif \\
\hline basit & 3514 & Negatif & negatif & 58 & Negatif & yolla & 20 & Negatif \\
\hline siradan & 3475 & Negatif & yalnızca & 58 & Negatif & azaltan & 19 & Negatif \\
\hline fazla & 2022 & Negatif & yabancı & 57 & Negatif & tepkiler & 18 & Negatif \\
\hline geniş & 1829 & Negatif & karmaşık & 56 & Negatif & tepkisi & 18 & Negatif \\
\hline kötü & 1796 & Negatif & Risk & 54 & Negatif & tipik & 18 & Negatif \\
\hline pahalı & 1783 & Negatif & zayif & 54 & Negatif & yavaş & 18 & Negatif \\
\hline sertlik & 1747 & Negatif & taklit & 53 & Negatif & aksi & 17 & Negatif \\
\hline düşüktür & 1740 & Negatif & küçük & 45 & Negatif & riskleri & 17 & Negatif \\
\hline hayalperest & 1737 & Negatif & zarar & 41 & Negatif & uzak & 17 & Negatif \\
\hline endişeli & 1736 & Negatif & hiçbir & 39 & Negatif & yetersiz & 17 & Negatif \\
\hline alçak & 1735 & Negatif & tepki & 39 & Negatif & zorunlu & 17 & Negatif \\
\hline çekingen & 1735 & Negatif & zordur & 39 & Negatif & tıpkı & 16 & Negatif \\
\hline berbat & 1734 & Negatif & çıkar & 38 & Negatif & eksik & 15 & Negatif \\
\hline dengesizlik & 1734 & Negatif & riski & 38 & Negatif & olmamaktadır & 14 & Negatif \\
\hline gergin & 1734 & Negatif & bask1 & 37 & Negatif & olmayacaktır & 14 & Negatif \\
\hline kayg11 & 1734 & Negatif & karşın & 34 & Negatif & olmaz & 14 & Negatif \\
\hline kibirlilik & 1734 & Negatif & yoktur & 34 & Negatif & tutucu & 14 & Negatif \\
\hline öfkeli & 1734 & Negatif & oynar & 32 & Negatif & başarısız & 13 & Negatif \\
\hline düşük & 1598 & Negatif & genişlemesi & 30 & Negatif & edilemez & 13 & Negatif \\
\hline fiyatlı & 1472 & Negatif & yaşl1 & 29 & Negatif & maço & 13 & Negatif \\
\hline boşa & 648 & Negatif & sert & 27 & Negatif & maruz & 13 & Negatif \\
\hline şikayetleri & 648 & Negatif & biraz & 26 & Negatif & sorunu & 13 & Negatif \\
\hline gitmez & 647 & Negatif & sorun & 26 & Negatif & tersi & 13 & Negatif \\
\hline şikâyetleri & 646 & Negatif & subjektif & 24 & Negatif & haksiz & 12 & Negatif \\
\hline fiziksel & 331 & Negatif & azaltır & 23 & Negatif & oysa & 12 & Negatif \\
\hline olumsuz & 188 & Negatif & benzerlik & 23 & Negatif & pasif & 12 & Negatif \\
\hline psikolojik & 157 & Negatif & markasız & 23 & Negatif & riskini & 12 & Negatif \\
\hline değildir & 149 & Negatif & sübjektif & 23 & Negatif & değilse & 11 & Negatif \\
\hline kisa & 94 & Negatif & zorunda & 22 & Negatif & gürültü & 11 & Negatif \\
\hline ucuz & 79 & Negatif & kritik & 21 & Negatif & kriz & 11 & Negatif \\
\hline olmadiğ 1 & 64 & Negatif & maliyet & 20 & Negatif & olmayıp & 11 & Negatif \\
\hline eski & 63 & Negatif & olmayabilir & 20 & Negatif & ödeme & 11 & Negatif \\
\hline sorumluluk & 8794 & Pozitif & güvenirim & 3471 & Pozitif & genç & 1808 & Pozitif \\
\hline kaliteli & 8286 & Pozitif & cesaretli & 3470 & Pozitif & yakın & 1808 & Pozitif \\
\hline güvenilir & 7861 & Pozitif & sadelik & 3470 & Pozitif & yaratıc1 & 1807 & Pozitif \\
\hline duygusal & 7465 & Pozitif & önde & 3411 & Pozitif & ilgi & 1806 & Pozitif \\
\hline tanınmış & 7330 & Pozitif & yeterli & 3124 & Pozitif & ciddi & 1794 & Pozitif \\
\hline tavsiye & 6885 & Pozitif & iyidir & 3026 & Pozitif & arkadaşça & 1793 & Pozitif \\
\hline moda & 6423 & Pozitif & temel & 2953 & Pozitif & güvenilirlik & 1791 & Pozitif \\
\hline güvenli & 6314 & Pozitif & sağlam & 2885 & Pozitif & modern & 1790 & Pozitif \\
\hline lider & 6266 & Pozitif & gelişmiş & 2856 & Pozitif & verici & 1788 & Pozitif \\
\hline yüksektir & 6074 & Pozitif & havalı & 2825 & Pozitif & uyumlu & 1786 & Pozitif \\
\hline yenilikçi & 5235 & Pozitif & eşsiz & 2722 & Pozitif & geleneksel & 1785 & Pozitif \\
\hline üstün & 5171 & Pozitif & güçlü & 2639 & Pozitif & çağdaş & 1783 & Pozitif \\
\hline farkl1 & 4894 & Pozitif & çekici & 2532 & Pozitif & yönlü & 1781 & Pozitif \\
\hline samimi & 4591 & Pozitif & kolayca & 2442 & Pozitif & doğal & 1778 & Pozitif \\
\hline duyarlı & 4582 & Pozitif & ünlü & 2437 & Pozitif & estetik & 1775 & Pozitif \\
\hline sofistike & 4565 & Pozitif & güvenilirdir & 2380 & Pozitif & bağımsız & 1772 & Pozitif \\
\hline prestij & 4556 & Pozitif & lükstür & 2380 & Pozitif & kolaylıkla & 1772 & Pozitif \\
\hline heyecan & 4214 & Pozitif & arkadaş & 2363 & Pozitif & düzenli & 1766 & Pozitif \\
\hline sosyal & 3843 & Pozitif & önemli & 2318 & Pozitif & emin & 1764 & Pozitif \\
\hline kurumsal & 3836 & Pozitif & değer & 2309 & Pozitif & cesur & 1762 & Pozitif \\
\hline temsil & 3634 & Pozitif & güven & 2024 & Pozitif & güvence & 1762 & Pozitif \\
\hline açık & 3544 & Pozitif & mutlu & 2018 & Pozitif & eğlenceli & 1759 & Pozitif \\
\hline kültürel & 3522 & Pozitif & başarılı & 1997 & Pozitif & popüler & 1759 & Pozitif \\
\hline
\end{tabular}




\begin{tabular}{|c|c|c|c|c|c|c|c|c|}
\hline güzel & 3513 & Pozitif & basar1 & 1975 & Pozitif & sicak & 1759 & Pozitif \\
\hline dinamik & 3500 & Pozitif & çeşitli & 1983 & Pozitif & güncel & 1756 & Pozitif \\
\hline neşeli & 3497 & Pozitif & görsel & 1949 & Pozitif & klasik & 1754 & Pozitif \\
\hline istikrarl1 & 349 & Pozitif & canlı & 1948 & Pozitif & enerjik & 1753 & Pozitif \\
\hline açıklık & 3492 & Pozitif & özel & 1871 & Pozitif & zeki & 1753 & Pozitif \\
\hline prestijli & 3480 & Pozitif & gerçek & 1869 & Pozitif & deneyimsel & 1751 & Pozitif \\
\hline dikkatli & 3480 & Pozitif & etkin & 1836 & Pozitif & atletik & 1745 & Pozitif \\
\hline gerçekçi & 3481 & Pozitif & yeni & 1833 & Pozitif & baskın & 1745 & Pozitif \\
\hline romantik & 3473 & Pozitif & değerli & 1821 & Pozitif & & & \\
\hline girişken & 3471 & Pozitif & Heyecanlı & 1814 & Pozitif & & & \\
\hline yüksek & 6870 & Nötr & Sektörde & 662 & Nötr & sembol & 226 & Nötr \\
\hline kalite & 6123 & Nötr & Fiziki & 661 & Nötr & Pazar & 218 & Nötr \\
\hline kalitesi & 5480 & Nötr & Ölçüm & 661 & Nötr & işletmeler & 214 & Nötr \\
\hline firma & 3650 & Nötr & Bazlı & 660 & Nötr & ülke & 214 & Nötr \\
\hline müşteri & 3605 & Nötr & hafizalarda & 660 & Nötr & isim & 213 & Nötr \\
\hline kişilik & 2825 & Nötr & Kocaman & 657 & Nötr & benzer & 207 & Nötr \\
\hline teknik & 2540 & Nötr & Çıkarsa & 651 & Nötr & tüketicilere & 206 & Nötr \\
\hline ürün & 2381 & Nötr & Modeller & 651 & Nötr & işletme & 195 & Nötr \\
\hline $\log 0$ & 2068 & Nötr & sergileyen & 651 & Nötr & hizmetin & 192 & Nötr \\
\hline rakip & 1923 & Nötr & Kullandığımda & 648 & Nötr & özellikle & 190 & Nötr \\
\hline özellik & 1901 & Nötr & Benim & 647 & Nötr & soyut & 185 & Nötr \\
\hline alışveriş & 1822 & Nötr & İmajının & 567 & Nötr & anlam & 184 & Nötr \\
\hline yerel & 1786 & Nötr & hedef & 458 & Nötr & belli & 176 & Nötr \\
\hline hayal & 1779 & Nötr & kavramı & 430 & Nötr & imajin & 173 & Nötr \\
\hline erkeksi & 1772 & Nötr & reklam & 428 & Nötr & unsurları & 172 & Nötr \\
\hline dönük & 1768 & Nötr & tercih & 425 & Nötr & sembolik & 168 & Nötr \\
\hline fiyata & 1765 & Nötr & sadece & 351 & Nötr & dolayı & 165 & Nötr \\
\hline ilgisi & 1757 & Nötr & uzun & 341 & Nötr & oldukça & 165 & Nötr \\
\hline halka & 1752 & Nötr & Kuru & 330 & Nötr & üretici & 164 & Nötr \\
\hline imaj & 1736 & Nötr & $\begin{array}{l}\text { konumlan- } \\
\text { dırma }\end{array}$ & 304 & Nötr & ticari & 163 & Nötr \\
\hline kimlik & 1706 & Nötr & Tüketiciye & 290 & Nötr & İlişki & 161 & Nötr \\
\hline aynı & 1686 & Nötr & Birçok & 280 & Nötr & görülmektedir & 160 & Nötr \\
\hline hizmet & 1207 & Nötr & Özellikler & 277 & Nötr & dolayısıyla & 159 & Nötr \\
\hline sahip & 1050 & Nötr & Başka & 266 & Nötr & Finansal & 158 & Nötr \\
\hline kişisel & 1027 & Nötr & Ürüne & 258 & Nötr & Somut & 156 & Nötr \\
\hline pazarlama & 850 & Nötr & Şekil & 253 & Nötr & Genellikle & 146 & Nötr \\
\hline derece & 769 & Nötr & Bağlı & 249 & Nötr & İnsan & 146 & Nötr \\
\hline duyarım & 703 & Nötr & İlişkin & 242 & Nötr & Özelliği & 140 & Nötr \\
\hline kullanan & 698 & Nötr & Tutum & 238 & Nötr & Yaşam & 140 & Nötr \\
\hline para & 687 & Nötr & Alan & 234 & Nötr & İmajına & 138 & Nötr \\
\hline hemen & 686 & Nötr & Kavram & 231 & Nötr & Durum & 137 & Nötr \\
\hline
\end{tabular}

\subsection{Doğrulama (Validation) Adımı}

Duygu analizinin önünde birtakım engeller mevcuttur. Bunlar; iğneleyici ifadeler ve ironiler, duygu sözcü̆ğü yokluğu, karmaşık yapı, gürültülü veri, olumsuzluk ekleri ve bu engellerin en başında gelen alan bağımlılık kısıtı, analizlerin etkin bir şekilde yapılamamasına neden olmaktadır. Örneğin "Bugün hava çok sıcak, adeta nefes alamıyorum" ve "Sicak satış yeteneği ile ön plana çıkıyor" cümlelerindeki sıcak kelimesi ilk cümlede negatif polarite ifade ederken ikinci cümlede nötr bir polarite göstermektedir (Pradhan vd., 2016; Karoui vd., 2019; Liu, 2020).

Alan bağımlılığını ortadan kaldırmak adına, bu çalışmada duygu sözlüğü kütüphanesinin geçerliliği aşağıdaki aşamalar ile test edildi: Etiketleme adımının geçerliliği için veri setinin içerisinden rastgele seçilen \%10' luk bir kısım, alanında uzman 10 kişiye tekrar etiketlendirildi. Sonuçlar karşılaştırıldığında \%95 oranında başarı oranı elde edildi. Bu oranlar Tablo 15’ de verilmiştir. 
Tablo 15

Duygu Skorlama Doğruluk Oranları

\begin{tabular}{lccc}
$\begin{array}{l}\text { Puanlama Yapan } \\
\text { Kişiler }\end{array}$ & $\begin{array}{c}\text { Doğru Skorlanan Kelime } \\
\text { Sayıları }\end{array}$ & $\begin{array}{c}\text { Yanlış Skorlanan Kelime } \\
\text { Sayıları }\end{array}$ & $\begin{array}{c}\text { Her Puanlayıcının Doğruluk } \\
\text { Oranı (\%) }\end{array}$ \\
\hline 1. Kişi & 883 & 70 & 0,93 \\
2. Kişi & 901 & 52 & 0,95 \\
3. Kişi & 909 & 44 & 0,95 \\
4. Kişi & 899 & 54 & 0,94 \\
5. Kişi & 903 & 50 & 0,95 \\
6. Kişi & 867 & 86 & 0,91 \\
7. Kişi & 888 & 65 & 0,93 \\
8. Kişi & 913 & 40 & 0,96 \\
9. Kişi & 920 & 33 & 0,97 \\
10. Kişi & 923 & 30 & 0,97 \\
Toplam & $\mathbf{9 0 0 6}$ & $\mathbf{5 2 4}$ & $\mathbf{9 5}(\boldsymbol{\%}$ Ortalaması) \\
\hline
\end{tabular}

Ayrıca bu çalışmada yer alan bazı kelimeler “marka imajı” terimi kapsamında skorlandığı için genel sözlüklerde ki skorlamalar ile benzeşmemektedir. Aşağıda bazı örnekler yer almaktadır.

Mohammad ve Turney (2013) tarafından geliştirilen ve en kapsamlı duygu sözlüğü olarak bilinen NRC (Emolex) 14.182 adet genel amaçlı duygu sözcüğü içermektedir. Bu sözcükler içerisinde bu çalışma kapsamında;

Örneğin "X markasının montları oldukça havalı gösteriyor."

"Havalı" sözcüğü marka imajı kapsamında değerlendirildiğinde prestiji vurgular ve pozitif bir duygu polaritesine sahiptir. Öte yandan genel anlamına bir örnek olarak,

"Dünyada havalı insanlar oldukça fazladır".

Cümlesindeki “Havalı” sözcüğü NRC sözlüğünde herhangi duygu belirtmemektedir. Bunun gibi birkaç örnek Tablo 16 ‘de yer almaktadir.

Tablo 16

Genel Sözlük ile Marka Alanı Sözlüklerinin Polarite Karşılaştırılması

\begin{tabular}{|c|c|c|c|c|c|}
\hline Kelime & NRC Polaritesi & $\begin{array}{c}\text { Marka İmajı Polar- } \\
\text { itesi }\end{array}$ & Kelime & NRC Polaritesi & $\begin{array}{c}\text { Marka İmajı Polar- } \\
\text { itesi }\end{array}$ \\
\hline Yerli & Nötr & Pozitif & Havalı & Nötr & Pozitif \\
\hline Bol & Nötr & Pozitif & Sicak & Nötr & Pozitif \\
\hline S1klıkla & Nötr & Pozitif & Katkısız & Nötr & Pozitif \\
\hline
\end{tabular}

\subsection{Görselleştirme (Visualization) Adımı}

R programlama dilinin imkân verdiği veri görselleştirme araçları ile metin madenciliği ve duygu analizinde kullanılan kelime bulutu görselinden yararlanılarak, metinlerde en çok geçen ilk 100 kelime bir bulut kümesi içerisinde gösterilmiştir. En sık geçen sorumluluk en büyük punto ile şekil 4 ile görselleştirilmiştir. 


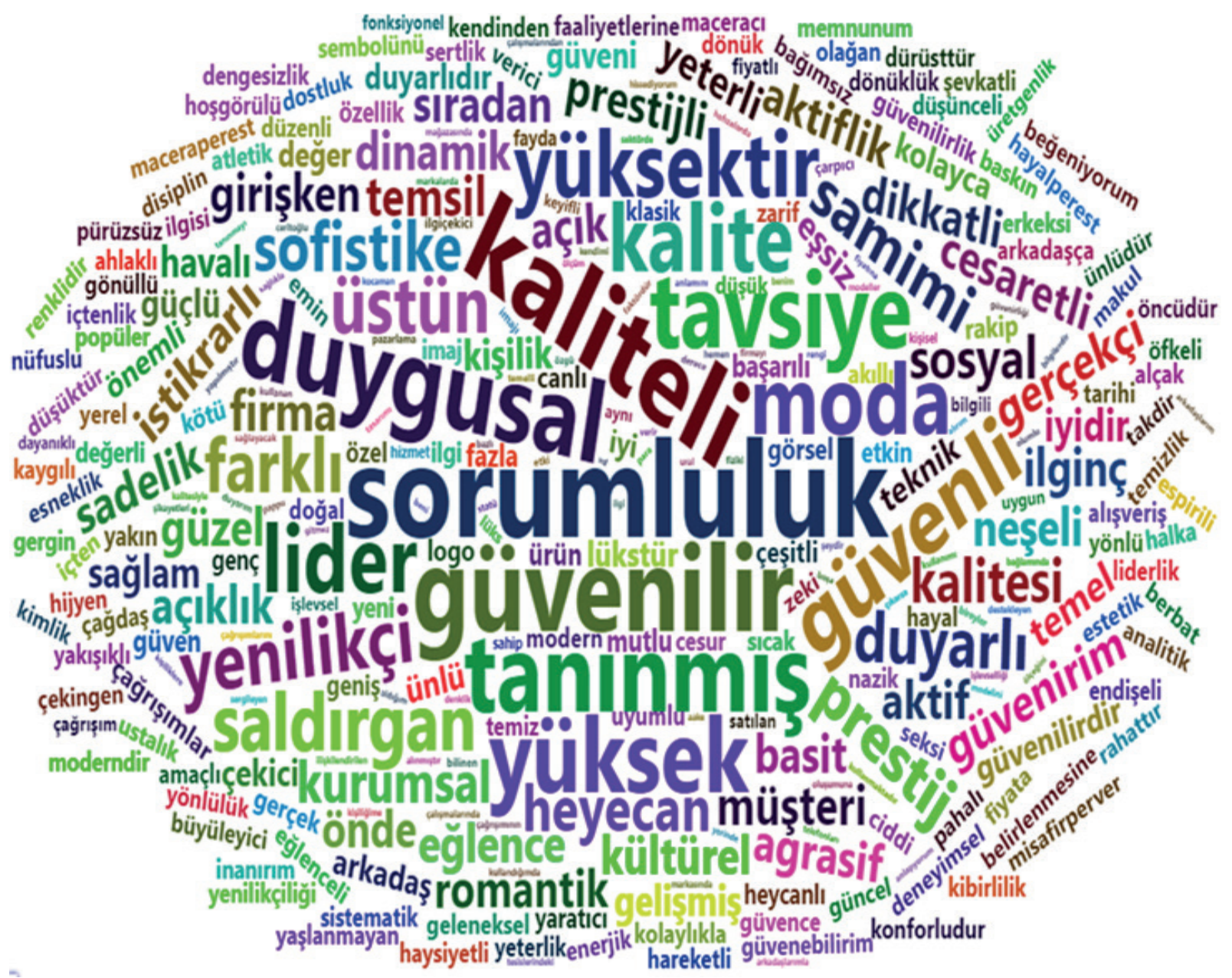

Şekil 4. En Sik Geçen İlk 100 Kelime Bulutu

\section{SONUÇ}

Günümüz hızlı rekabet koşullarında, endüstri, akademi, hizmet, devlet ve teknoloji gibi farklı sektörlerde ve farklı disiplinlerde tüketici gereksinimleri ve öncelikleri oldukça dinamik ve hızlı bir şekilde değişmektedir. Değişen ve gün geçtikçe artan bu ihtiyaç ve beklentileri zamanında fark edebilmek ve farklılaşan niteliklere cevap verebilmek oldukça önem arz etmektedir. Firmaların hem sektör itibari ile hem de piyasalarda lider olabilmesi, rakiplerine göre daha güçlü olarak onlardan bir adım önde olabilmesi ve bu başarısını sürdürmesi rakiplerinden farklılaşma göstermesine bağlıdır. Firmaların farklılık yaratmaları, tüketicilerin zihinlerinde marka aşinalığı sağlamak ve olumlu bir şekilde konumlanmaları ile mümkün olabilmektedir (Jones, 2010).

Bu çalışmada, marka imajı alanında Türkçe kaynaklı bir duygu sözlüğü geliştirmek hedeflenmiştir. Çalışmada cevap aranan sorulardan biri, literatürde marka imajı alanında kullanılan kelimelerin neler olduğu şeklindedir. Bu soruya cevap vermek amacıyla, marka imajı alanındaki literatürü tarayarak Türkçe olarak ifade eden 113 yüksek lisans ve doktora tezi çalışma kapsamına alınmıştır. Bu tezlerden marka imajı ile ilgili, 31.673 adet ön işlemden geçmiş kelime içerisinde 9535 adet duygu ifade eden kelimeye ulaşılmıştır. Literatürde marka imajı kapsamında en çok kullanılan Türkçe kelime sayısı 9535 adet olarak bulunmuştur. Diğer araştırma sorusu, marka imajını karakterize eden duygular ve bu duygulara ait kelimelerin neler olduğudur. Bu kapsamda, elde edilen kelimelerin üç temel duyguyu ifade ettiğini söylemek mümkündür. Bu duygular pozitif, negatif ve nötr olarak ifade edilebilir. Marka imajı bağlamında elde edilen 9535 kelime bu duygular bazında sınıflandırılmıştır. Böylece kelimelerin yaklaşık \%41'i pozitif duygu, \%22'si negatif duygu ve \%37'si de nötr duygu bildiren kelimelerden oluşmaktadır. Literatürde marka imajını niteleyen ve pozitif duygu bildiren kelimeler arasında en sık kullanılanlar "sorumluluk", 
"kaliteli”, "güvenilir", "tanınmış", "güvenli” ve "lider” gibi kelimeler gelmektedir. En sık geçen negatif duygu bildiren kelimeler arasında "saldırgan”, "basit”, "sıradan”, "pahalı” ve kötü” kelimeleri yer almaktadır. Nötr duygu bildiren kelimelerden en sık kullanılanlar ise "kalite", "firma”, “yüksek”, "müşteri”, "kişilik” ve "ürün” dür. Uygulama kapsamında geliştirilen sözlükteki temel duygulara ait kelimelerin $\% 95$ oranındaki doğrulanma oranı, bu sözlük çalışmasının geçerlilik ve güvenirlilik düzeyinin de yeterince yüksek bir seviyede olduğunu göstermektedir.

Elde edilen marka imajı sözlüğü kapsamında marka imajını niteleyen kelimelerin yer alması markanın geneline yönelik toplam tutum ve çağrışımları ölçmemize olanak tanımaktadır. Bu tutum ve çağrışımlardan hareketle, tüketicilerin hangi faktörlere vurgu yaptığının altı çizilirken konumlandırma faaliyetlerimizin tüketiciler nezdinde ne kadar etkili olup olmadığını da görmemiz bakımından faydalı bir niteliktedir. Alternatif ve görece daha kolay bir yönteme dayanarak geliştirilen marka imajı sözlük çalışması, kendi markamız dışındaki markaların imajlarını da rekabetçi bir biçimde keşfedilmesine olanak sağlamaktadır. Rekabet edilen alandaki mevcut tüketici algı yapısının nasıl olduğuna yakından bakılarak negatif faktörlerin ve pozitif faktörlerin karşılaştırılması yapılabilecektir. Bu alanlardaki konumlarına ilişkin derinlemesine değerlendirme imkânı elde edebileceklerdir. Örneğin markalar rakiplerine kıyasla ayrışmak istiyorlar ise duygu analizi sonucu ortaya çıkan en yüksek pozitif duygu değerlerine odaklanmalıdırlar. Daha başarılı bir marka yönetimi stratejisi benimsemek istenir ise de, analiz sonucu elde edilen en yüksek negatif duygu bildiren faktörlerin üzerinde yoğunlaşmalıdırlar.

$\mathrm{Bu}$ çalışma aşağıda belirtileceği üzere birtakım sınırlılıklara sahip olmakla birlikte, Türkçe kaynaklı sözlük çalışmalarının çok sınırlı olması ve genel anlamdaki sözlüklerin belirli bir alana özgü görüşleri ortaya çıkarmada yetersiz kalması gibi problemler duygu analizi çalışmalarında önemli bir engel teşkil etmektedir. Bu anlamda bu çalışmanın, marka imajı alanına özel ilk Türkçe kaynaklı sözlük çalışması olması bakımından önemli olduğu düşünülmektedir. Ayrıca "alana özgü sözlük çalışması" için bir örnek teşkil etmektedir. Bu bağlamda marka imajı ile ilgili yapılması planlanan duygu analizi çalışmalarının geleceği için ümit vermekte ve gelecekteki çalışmalar için akademisyenlere başlangıç noktası oluşturabileceği düşünülmektedir. Bunun yanı sıra, geliştirilen bu duygu sözlüğünün, sektör itibari ile hızlı değişim ve dönüşüm gerektiren günümüz koşullarında işletmeler için de markalarının sahip olduğu konumu anlık olarak fark edebilmelerine imkân sağlayarak, olumlu yöndeki duygu ifadelerini tespit edip rekabet avantajı sağlayacak stratejiler geliştirmeleri, olumsuz yöndeki duygu ifadeleri için de zamanında önlemler almaları ve markalarını daha güçlü bir şekilde yönetebilmeleri bakımından fayda sağlayacağı umulmaktadır. Geliştirilen "marka imajı duygu sözlüğüne" aşağıdaki linkten ulaşılabilirsiniz:

https://github.com/istanbulum/marka-imaj-duygu-sozlugu/blob/master/lexicon\%20dictionary.csv

Hakem Değerlendirmesi: Dış bağımsız.

Çıkar Çatışması: Yazarlar çıkar çatışması bildirmemiştir.

Finansal Destek: Yazarlar bu çalışma için finansal destek almadığını beyan etmiştir.

Peer-review: Externally peer-reviewed.

Conflict of Interest: The authors have no conflict of interest to declare.

Grant Support: The authors declared that this study has received no financial support.

\section{Kaynaklar/References}

Aaker, D.A.\& Biel, A.L. (1993). Brand Equity Ve Advertising: Advertising's Roles In Building Strong Brands. Lawrence Erlbaum Associates, New Jersey. Abdul-Mageed, M., Diab, M.T. \& Korayem, M. (2011). Subjectivity And Sentiment Analysis Of Modern Standard Arabic, The 49th Annual Meeting Of The Association For Computational Linguistics (Short Papers), 587-591.

Abdul-Mageed, M., Kübler, S. \& Diab, M. (2012). SAMAR: A System For Subjectivity And Sentiment Analysis Of Arabic Social Media, Proceedings Of The 3rd Workshop İncomputational Approaches To Subjectivity And Sentiment Analysis, 28(1), 20-37.

Akbaş, E., (2012). Aspect Based Opinion Mining On Turkish Tweets, Yüksek Lisans Tezi, Bilkent Üniversitesi, Mühendislik ve Fen Bilimleri Enstitüsü, Ankara. Akhtar.

Akgül, E.S., Ertano, C. \& Diri, B. (2016). Twitter Verileri İle Duygu Analizi. Pamukkale Üniversitesi Mühendislik Bilimleri Dergisi, 22(2), 106-110.

Al-Ayyoub, M., Essa, B.S. \& Alsmadi, I. (2015). Lexicon-Based Sentiment Analysis Of Arabic Tweets, Int. J. Social Network Mining, 2(2), 101-114.

Aue, A. \& Gamon, M. (2005). Customizing Sentiment Classifiers To New Domains: A Case Study, In Proceedings Of The International Conference On

Recent Advances İn Natural Language Processing, Borovets, Bulgaria. 
Aytekin, Ç., (2013). An Opinion Mining Task İn Turkish Language A Model For Assigning Opinions İn Turkish Blogs To The Polarities, Journalism And Mass Communication, 3, 179-198.

Baccianella, S., Esuli, A., \& Sebastiani, F. (2010). Sentiwordnet 3,0: An Enhanced Lexical Resource For Sentiment Analysis And Opinion Mining, Proceedings Of The 7th International Conference On Language Resources And Evaluation, 10, 2200-2204.

Balahur, A., Hermida, J.M. \& Montoyo, A., (2012). Detecting Implicit Expressions Of Emotion İn Text: A Comparative Analysis, Decision Support Systems, 53, 742-753.

Bartlett, J. ve Albright, R. (2008). Coming To A Theater Near You! Sentiment Classification Techniques Using SAS Text Miner, In SAS Global Forum, San Antonio, TX.

Başfırıncı, Ç. (2016). Marka İmajının Sosyal Ağ Analizi ile İncelenmesi: Turkcell ve Vodafone Markalarına Yönelik Bir Araştırma, İstanbul Gelişim Üniversitesi Sosyal Bilimler Dergisi 3(2), 25-50. doi: 10.17336/igusbd.30297

Bilgin, O., Çetinoğlu, Ö. \& Oflazer, K. (2004). Building A Wordnet For Turkish, Romanian Journal Of Information Science And Technology, 7(1-2), $163-172$.

Boiy, E., Hens, P., Deschacht, K. \& Moens, M.F., (2007). Automatic Sentiment Analysis Of On-Line Text, In Proceedings Of The 11th International Conference On Electronic Publishing, 349-360, Vienna.

Boldrini, E., Balahur A., Martı'Nez-Barco, P. \& Montoyo A. (2012). Using Emotiblog To Annotate And Analyse Subjectivity İn The New Textual Genres, Data Mining Knowlage Discovery, 25, 603-34.

Canan, S. (2013). Bir Halkla İlişkiler Aracı Olarak Sosyal Medya Kullanımı: Üç Alana Yönelik Bir İnceleme.Yüksek Lisans Tezi, İstanbul Üniversitesi Sosyal Bilimler Enstitüsü Halkla İlişkiler ve Tanıtım Anabilim, İstanbul.

Cebeci, H.İ. (2020). Mühendislikte Yapay Zekâ ve Uygulamaları 3: Sosyal Medya Verileri ile Duygu Analizi (191-211). Sakarya Üniversitesi Mühendislik Fakültesi, Sakarya: Sakarya Üniversitesi.

Chaovalit, P. \& Zhou, L. (2005). Movie Review Mining: A Comparison Between Supervised And Unsupervised Classification Approaches, In Proceedings Of The 38th Hawaii International Conference On System Sciences, Hawaii.

Chen, M., Mao S., Zhang Y., \& Leung V.C.M. (2014). Big Data Related Technologies, Challenges And Future Prospect. Springer Briefs İn Computer Science, 2-3.,Newyork, Springer.

Chia-Hung, H. (2008). The Effect Of Brand İmage On Public Relations Perceptions And Customer Loyalty. International Journal Of Management, 25(2): 237- 246.

Christodoulides, G. \& De Chernatony, L. (2010). Consumer-Based Brand Equity Conceptualization And Measurement: A Literature Review. International Journal Of Market Research, 52 (1), 43-66.

Clow, K., Baack, D. (2016). Bütünleşik Reklam, Tutundurma Ve Pazarlama İletişimi. Ankara: Nobel Akademik Yayıncılık.

Copeland, M.T. (1923). Relation Of Consumers' Buying Habits To Marketing Methods. Harvard Business Review, 1(3), $282-289$.

Davcik, N.S. \& Rundquist, J. (2012). An Exploratory Study Of Brand Success: Evidence From The Food İndustry. Journal Of International Food And Agribusiness Marketing, 24 (1), 1-119.

Dehkharghani, R., Saygin, Y., Yanikoglu, B., \& Oflazer, K. (2015). Sentiturknet: A Turkis Polarity Lexicon For Sentiment Analysis, Language Resources And Evaluation, 50(3), 667-685.

Ding, X., Liu, B., ve Yu, P. S. (2008). A Holistic Lexicon-Based Approach To Opinion Mining, Proceedings Of The 2008 International Conference On Web Search And Data Mining, 231-240.

Esuli A. \& Sebastiani F. (2006). Sentiwordnet: A Publicly Available Lexical Resource For Opinion Mining, In Proceedings of 5th International Conference on Language Resources and Evaluation (LREC), 417-422.

Fellbaum, C. (1998). Wordnet: An Electronic Lexical Database, MIT Press.

Fernández-Gavilanes, M., Álvarez-López, T., Juncal-Martínez, J., Costa-Montenegro, E. \& González-Castaño, F.J. (2016). Unsupervised Method For Sentiment Analysis İn Online Texts, Expert Syst. Appl. 58, 57-75.

Gardner, B.B. \& Levy, S. J. (1955). The Product And The Brand. Harvard Business Review 33-39.

Hatzivassiloglou, V. ve Mckeown, K. (1997). Predicting The Semantic Orientation Of Adjectives, In Proceedings Of 35th Meeting Of The Association For Computational Linguistics, 174-181.

Hu, M., \& Liu, B. (2004). Mining And Summarizing Customer Reviews, İn Proceedings Of The Tenth ACM SIGKDD International Conference On Knowledge Discovery And Data Mining, New York, 168-177.

İdeasoft, (2021). https://www.İdeasoft.Com.Tr/Marka-Konumlandirma-Nedir/ (Erişim 25.07.2021)

İş verileri platformu,(2020) http/www.statista.com/topics/1164/social-networks/(Erişim, 20.01.2020).

Jones, R. (2010). Corporate Branding: The Role Of Vision İn İmplementing The Corporate Brand, Innovative Marketing, 6 (1),44-57.

Kang, D.\& Park, Y., (2014). Review-Based Measurement Of Customer Satisfaction İn Mobile Service: Sentiment Analysis And VIKOR Approach, Expert Systems With Applications, 41, 1041-1050.

Kang, H., Yoo, S.J. \& Han, D. (2012). Senti-Lexicon And Improved Naïve Bayes Algorithms For Sentiment Analysis Of Restaurant Reviews, Expert Systems With Applications, 39, 6000-6010.

Karoui, J., Zitoune, F. B. \& Moriceau, V. (2019). Automatic Detection Of Irony, John Wiley \& Sons.

Kaufmann, JM. Jmaxalign, (2012). A Maximum Entropy Parallel Sentence Alignment Tool, In: Proceedings Of COLING'12: Demonstration Papers, Mumbai, 277-88.

Kaya, M., Fidan, G.\& Toroslu, I.H. (2012). Sentiment Analysis Of Turkish Political News, In Proceedings Of WI-IAT'12 IEEE/WIC/ACM International Joint Conferences On Web İntelligent Agent Technology, Macau, Çin, 174-180. 
Kennedy, A. \& Inkpen, D. (2006). Sentiment Classification Of Movie And Product Reviews Using Contextual Valence Shifters, Computational Intelligence, 22(2):110-125.

Khan, F.H., Qamar, U. \& Bashir, S. (2016). Esap: A Decision Support Framework For Enhanced Sentiment Analysis And Polarity Classification, Information Sciences, 367(368), 862-873. doi: 10.1016/j.ins.2016.07.028

Kouloumpis, E, Wilson, T.\& Moore, J. (2011). Twitter Sentiment Analysis: The Good The Bad And The Omg!, Proceedings Of The Fifth International AAAI Conference On Weblogs And Social Media (ICWSM), 538-541

Liu, B. (2020). Sentiment Analysis: Mining Opinions, Sentiments, And Emotions, Cambridge University Press.

Medhat, W., Hassan, A. \& Korashy, H., (2014). Sentiment Analysis Algorithms And Applications: A Survey, Ain Shams Engineering Journal, 5,10931113. doi: 10.1016/j.asej.2014.04.011

Meenaghan, T., (1995). The Role Of Advertising İn Brand Image Development. Journal Of Product Ve Brand Management., 4(4): 23-34.

Mohammad, S.M. \& Turney, P.D. (2013). Crowdsourcing A Word-Emotion Association Lexicon ( NRC), Computational Intelligence, 29(3), 436-465.

Nielsen, F. A. (2011). A New ANEW: Evaluation Of A Word List For Sentiment Analysis In Microblogs, In Proceedings of the ESWC2011 Workshop on 'Making Sense of Microposts': Big things come in small packages (pp. 93-98). CEUR Workshop Proceedings No. 718 http://research.hypios.com/ msm2011/ Workshop On Making Sense Of Microposts, 93-98.

Nigam, K. \& Hurst, M. (2004). Towards A Robust Metric Of Opinion, AAAI Spring Symposium On Exploring Attitude And Affect İn Text, 598-603.

Oza, K.S. \& Naik, P.G. (2016). Prediction Of Online Lectures Popularity: A Text Mining Approach” Procedia Computer Science, 92, 468-474. doi: 10.1016/j.procs.2016.07.369

Öztürk, N. \& Ayvaz, S. (2018). Sentiment Analysis On Twitter: A Text Mining Approach To The Syrian Refugee Crisis, Telematics And Informatics, 35(1), 136-147. doi: 10.1016/j.tele.2017.10.006

Park, C.S. \& Srinivasan, V. (1994). A Survey-Based Method For Measuring And Understanding Brand Equity And Its Extendibility. Journal Of Marketing Research, 31 (2), 271-288.

Park, S., Lee, W. \& Moon, I.C. (2015). Efficient Extraction Of Domain Specific Sentiment Lexicon With Active Learning, Pattern Recognition Letters, 56, 38-44. doi: 10.1016/j.patrec.2015.01.004

Paswan, A., Guzman, F., \& Blankson, C. (2012). Business To Busniess Governance Structure Andmarketing Strategy. Industrial Marketing Management, 41 (6), 908-918.

Pradhan, V. M., Vala, J.\& Balani, P. (2016). A Survey On Sentiment Analysis Algorithms For Opinion Mining”, International Journal Of Computer Applications, 133(9), 7-11.

Robaldo L. \& Di Caro L. (2012). Opinionmining-ML, Comput Stand Interfaces, 35(5),454-469.

Sevindi, B.İ. (2013). Türkçe Metinlerde Denetimli ve Sözlük Tabanlı Duygu Analizi Yaklaşımlarının Karşılaştırılması, Yüksek Lisans Tezi, Gazi Üniversitesi, Fen Bilimleri Enstitüsü, Ankara.

Smith, R.J. (1915). Market Distribution Discussion: J. Russell Smith. American Economic Review, 5(1), 157-158.

Srinivasan, V., Park, C. \& Chang, D. (2005). An Approach To The Measurement, Analysis And Prediction Of Brand Equity And Its Sources. Management Science, 51 (9). 1433-1448.

Steinberger J., Ebrahim M., Ehrmann M., Hurriyetoglu A., Kabadjov M., Lenkova P., Steinberger R., Tanev H., Va' Zquez S. \& Zavarella V. (2012). Creating Sentiment Dictionaries Via Triangulation, Decision Support System, 53, 689-94.

Stone, P.J., Dunphy, D.C., Smith, M.S. \& Ogilvie, D. M. (1966). The General Inquirer: A Computer Approach To Content Analysis, MIT Press, Cambridge.. Şimşek, M.U. \& Özdemir, S. (2012). Analysis Of The Relation Between Turkish Twitter Messages And Stock Market Index, In Procedings Of AICT ‘'12, 6th Conference On Application Of Information And Communication Technologies, Tiflis, Gürcistan, 1-4.

Taboada, M., Brooke, J., Tofiloski, M., Voll, K. \& Stede, M., (2011). Lexicon-Based Methods For Sentiment Analysis, Computational Linguistics, 37(2), 267-307.

Thelwall, M., Buckley, K., Paltoglou, G., Cai, D.\& Kappas, A. (2010). Sentiment Strength Detection İn Short İnformal Text, J. Am. Soc. Information Science Technologies, 61 (12), 2544-2558.

Tong, R. M. (2001). An Operational System For Detecting And Tracking Opinions İn On-Line Discussions, In Working Notes Of The ACM SIGIR Workshop Operational Text Classification, , New York, NY. 1-6.

Türkmenoğlu, C. (2015). Türkçe Metinlerde Duygu Analizi. İstanbul Teknik Üniversitesi, Bilgisayar Mühendisliği Abd, Yüksek Lisans Tezi, İstanbul.

Vural, G.A, Cambazoğlu, B.B., Senkul, P. \& Tokgoz, Ö. Z. (2012). A Framework for Sentiment Analysis In Turkish: Application To Polarity Detection Of Movie Reviews In Turkish, Computer And Information Science III., 437-445.

Wiebe J., Wilson T., \& Cardie C. (2005).Annotating Expressions Of Opinions And Emotions İn Language, Language Resources And Evaluation, 33(2-3), 164-210.

Xie, R. \& Li, C. (2012). Lexicon Construction: A Topic Model Approach, In Systems And Informatics (ICSAI), International Conference, $2299-2303$.

Yi, J., Nasukawa, T., Bunescu, R., \& Niblack, W. (2003). Sentimentanalyzer: Extracting Sentiments About A Given Topic Using Natural Language Processing Techniques, In: Proceedings Of Third IEEE International Conference on Data Mining, 427-434. 
